\title{
Iron isotope fractionation in sediments of an oligotrophic freshwater lake
}

\author{
by \\ Kai Liu
}

\begin{abstract}
A thesis
presented to the University of Waterloo

in fulfillment of the

thesis requirement for the degree of

Master of Science

in

Earth Sciences
\end{abstract}

Waterloo, Ontario, Canada, 2015

CKai Liu 2015 


\section{Author's Declaration}

This thesis consists of material all of which I authored or co-authored: see Statement of Contributions included in the thesis. This is a true copy of the thesis, including any required final revisions, as accepted by my examiners.

I understand that my thesis may be made electronically available to the public. 


\section{Statement of Contributions}

This thesis is written by Kai Liu and the co-authors. Kai Liu is the first author and carried out the studies with some input and direction from co-authors.

This study was completed under supervision of Dr. Lingling Wu. The study was supported by an NSERC Discovery grant awarded to Dr. Lingling Wu (no. RGPIN-2014-05453).

A version of this paper has been published for publication in Earth and Planetary Science Letters.

Liu, K., Wu, L., Couture, R-M., Li, W.,Van Cappellen, P.(2015) Iron

isotope fractionation in sediments of an oligotrophic freshwater lake.

Earth Planet. Sci. Lett. 423,164-172. 


\begin{abstract}
In situ iron (Fe) isotope compositions of pore water and solid-bound Fe phases were measured in sediments of an oligotrophic, sulfate-poor freshwater lake (Lake Tantaré, Québec, Canada). Previous work has shown that dissimilatory Fe(III) reduction $(\mathrm{DIR})$ is the main Fe reduction pathway in this setting. Hence, the lake sediments provide a well-characterized, natural environment in which to assess the transferability of DIR-produced Fe isotope fractionations obtained in laboratory model systems. Iron redox cycling within the sediments produces isotopically light pore water $\mathrm{Fe}(\mathrm{II})$ (average $\delta^{56} \mathrm{Fe}=-2.1 \pm 0.6 \%$ ) and sorbed $\mathrm{Fe}(\mathrm{II})$ (average $\delta^{56} \mathrm{Fe}=$ $-1.2 \pm 0.2 \%$ ), compared to the $\mathrm{Fe}(\mathrm{III})$ oxyhydroxide (average $\delta^{56} \mathrm{Fe}=+0.6 \pm 0.2 \%$ ) and tightly solid-bound $\mathrm{Fe}(\mathrm{II})$ (average $\delta^{56} \mathrm{Fe}=+0.3 \pm 0.2 \%$ ) sediment pools. The apparent isotope fractionation factor between aqueous $\mathrm{Fe}(\mathrm{II})$ and $\mathrm{Fe}(\mathrm{III})$ oxyhydroxides of $-2.6 \pm 0.5 \%$ derived for Lake Tantaré sediments falls within the range reported for experimentally determined isotopic fractionations during DIR. Our results yield the first comprehensive set of $\mathrm{Fe}$ isotope signatures associated with microbially driven Fe redox cycling obtained directly in sediments of an oligotrophic freshwater lake.
\end{abstract}

Keywords: Fe isotope fractionation, sediments, oligotrophic lake, pore water, dissimilatory iron reduction 


\section{Acknowledgement}

I would like to express my most gratitude and sincere respect to my supervior, Dr. Lingling $\mathrm{Wu}$ for her guidance and encouragement. The knowledge and research methods she taught will benefit me in further study and research in

geochemistry area. Without her expertise, patience encourage and insightful knowledge, I could hardly complete my thesis work.

I also would like to expree my sense of gratitude and indebtedness to my committee members: Dr. Philippe Van Cappellen and Dr. Raoul- Marie Couture for their timely advice and insightful ideas throughout the every stage of my research.

I owe a deep sense of thanks to Dr. Clark Johnson and Dr. Brian Beard at University of Wisconsin-Madison for training me on iron isotope analysis and also providing me valuable feed back that greatly improved my thesis.

I would like to thank Dr. Charles Gobeil and Dr. Jade Bergeron (Université du Québec, INRS-ETE) for providing pore water \& sediment samples.

I thank two anonymous journal reviewers for providing much appreciated comments and suggestions. 


\section{Table of Contents}

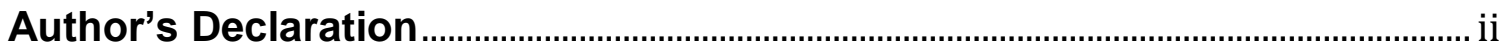

Statement of Contributions ........................................................................................ii

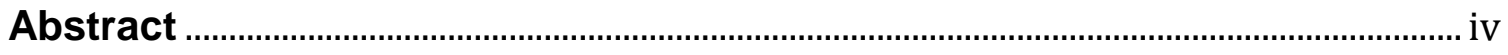

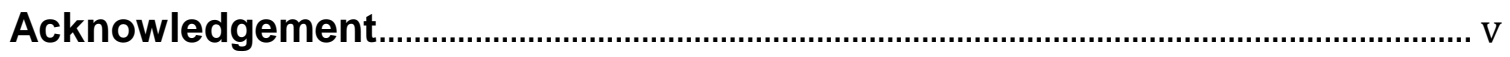

Content of Tables........................................................................................................... vi

List of Figures............................................................................................................. vii

List of Tables ..................................................................................................................... viii

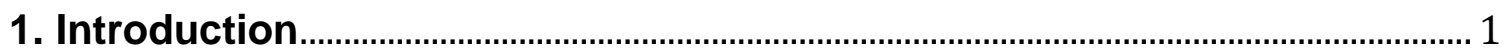

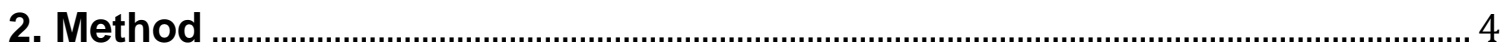

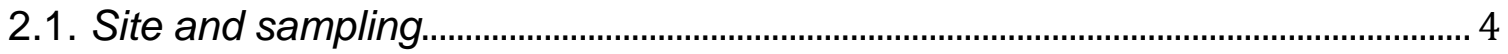

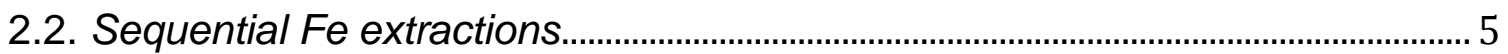

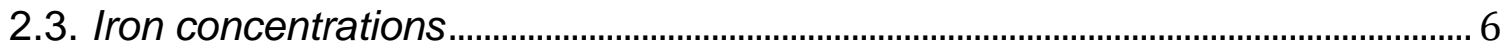

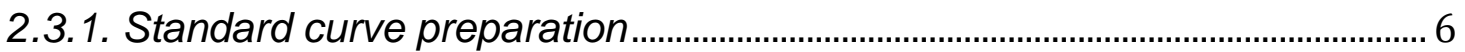

2.3.2. Ferrous and ferric iron concentration analysis for porewater samples.... 7

2.3.3. Ferrous and ferric iron concentration analysis for sediment samples...... 7

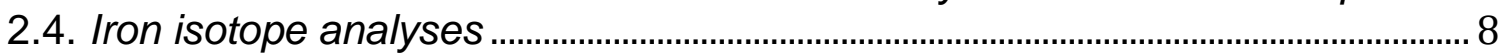

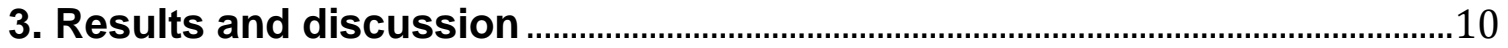

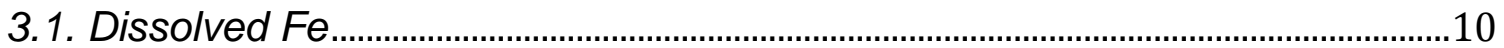

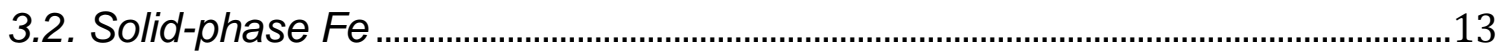

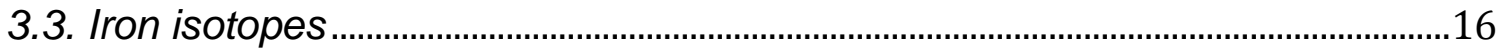

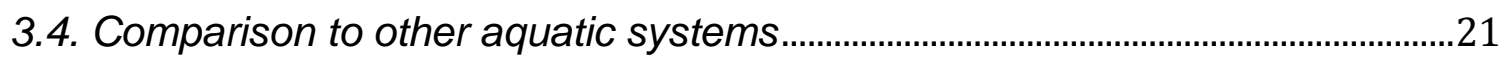

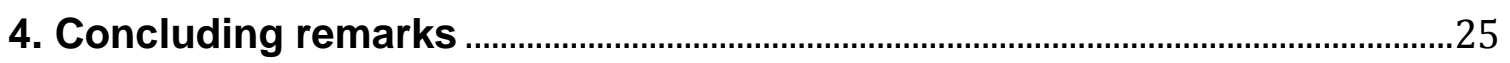

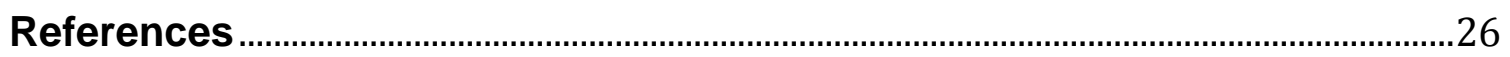

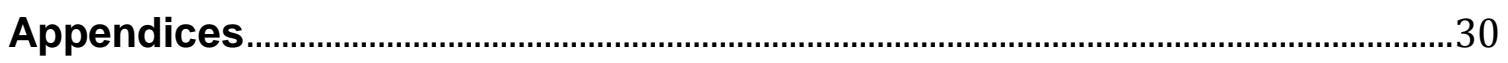




\section{List of Figures}

Fig. 1. Depth profiles of (a) the total pore water Fe concentration, and (b-d) the solid sediment Fe-pools derived from the sequential acid extractions.......

Fig. 2. Depth profiles of the concentration of total $\mathrm{Fe}\left(\mathrm{Fe}_{\text {sum }}\right)$ and $\mathrm{Fe}(\mathrm{II}) /$ total $\mathrm{Fe}$ ratio $\left(\mathrm{Fe}(\mathrm{II})_{\text {sum }} / \mathrm{Fe}_{\text {sum }}\right)$ for bulk sediments in Basin A.

Fig. 3. Measured iron isotope compositions for pore water and three sediment extractions( which is a mixture of $\mathrm{Fe}(\mathrm{II})$ and $\mathrm{Fe}(\mathrm{III})$ in Basin $\mathrm{A}$ (panel a) and only three sediment extractions in Basin B (panel b).....

Fig. 4. Frequency diagram of calculated $\mathrm{Fe}$ isotope compositions for different $\mathrm{Fe}$ phases( pore water $\mathrm{Fe}(\mathrm{II})$, sorbed $\mathrm{Fe}(\mathrm{II})$, tightly-bound $\mathrm{Fe}(\mathrm{II})$ and $\mathrm{Fe}(\mathrm{III})$ oxyhydroxides) in Basin A and Basin B

Fig. A. 1. Depth profiles of the concentrations of $\mathrm{Fe}(\mathrm{II})$ and $\mathrm{Fe}$ (III) for sediment extractions in Basin B

Fig. A. 2. Depth profiles of the concentration of total $\mathrm{Fe}\left(\mathrm{Fe}_{\text {sum }}\right)$ and $\mathrm{Fe}(\mathrm{II}) /$ total $\mathrm{Fe}$ ratio $\left(\mathrm{Fe}(\mathrm{II})_{\text {sum }} / \mathrm{Fe}_{\text {sum }}\right.$ ) for bulk sediments in Basin $\mathrm{B}$

Fig. A. 3. Calculated iron isotope compositions for different Fe phase(pore water $\mathrm{Fe}(\mathrm{II})$, sorbed $\mathrm{Fe}(\mathrm{II})$, tightly-bound $\mathrm{Fe}(\mathrm{II})$ and $\mathrm{Fe}(\mathrm{III})$ oxyhydroxides) in Basin $\mathrm{A}$ ( panel a) and Basin B (panel b). 


\section{List of Tables}

Table A. 1. Iron concentration for pore water samples from Basin A, Tantaré. ........30

Table A. 2. Iron concentration for sediments in Basin A, Tantaré...................................31

Table A. 3. Iron concentration for sediments in Basin B, Tantaré...................................32

Table A. 4. $\delta^{56} \mathrm{Fe}$ values for pore water samples from Basin A, Tantaré......................33

Table A. $5 . \delta^{56} \mathrm{Fe}$ values for sediments in Basin A, Tantaré. ............................................33

Table A. $6 \delta^{56} \mathrm{Fe}$ values for sediments in Basin B, Tantaré..............................................34

Table A. 7. $\delta^{56} \mathrm{Fe}$ values for sediments in Basin A, Tantaré.............................................34

Table A. 8. $\delta^{56} \mathrm{Fe}$ values for different iron phases and iron isotope mass balance in Basin B, Tantaré.

Table A. 9. Summary of iron isotope measurements and mass balance calculation for Basin A, Tantaré..

Table A. 10. Summary of iron isotope measurements and mass balance calculation for Basin B, Tantaré.

Table A. 11. Comparison of Fe isotope compositions in different aquatic systems. 


\section{Introduction}

The biogeochemical cycling of iron $(\mathrm{Fe})$ plays an important role in near-surface environments, because the electron transfer processes during $\mathrm{Fe}$ redox transformations are closely tied to reactions with other redox-sensitive elements, including oxygen (Millero et al., 1987), carbon (Lalonde et al., 2012), nitrogen (Straub et al., 1996), sulfur (Thamdrup et al., 1994), and contaminants such as chromium (Buerge and Hug, 1999). Furthermore, sorption to Fe oxyhydroxides can significantly influence the fate of oxyanions of nutrient elements, for example phosphorus (Hongve, 1997) and silicon (Davis et al., 2002), and trace elements (Belzile et al., 2000).

Iron isotopes provide a powerful tool to unravel Fe cycling processes, in modern and ancient Earth settings (e.g., Borrok et al., 2009; Johnson et al., 2008). Both biotic and abiotic processes can fractionate $\mathrm{Fe}$ isotopes; the largest fractionations are associated with redox transformations between ferric and ferrous Fe (Crosby et al., 2005; Wu et al., 2012). Oxidation of aqueous Fe(II) and reduction of solid $\mathrm{Fe}$ (III) phases may both generate isotopically light $\mathrm{Fe}(\mathrm{II})$. In the former case, the combination of equilibrium fractionation between aqueous $\mathrm{Fe}(\mathrm{II})$ and aqueous $\mathrm{Fe}(\mathrm{III})$ and kinetic fractionation upon precipitation of $\mathrm{Fe}(\mathrm{III})$ yields an overall fractionation of -1 to $-2 \%$, that is, values smaller than would be obtained under exclusively equilibrium conditions (Beard and Johnson, 2004; Wu et al., 2013). Dissimilatory $\mathrm{Fe}(\mathrm{III})$ reduction (DIR) has been shown to produce fractionations on the order of $-3 \%$, both in the laboratory and in natural settings (Crosby et al., 2005; 2007; Percak-Dennett et al., 2011; Tangalos et al., 2010). Abiotic reduction of $\mathrm{Fe}(\mathrm{III})$ oxide phases, for example through reaction with $\mathrm{H}_{2} \mathrm{~S}$ produced by microbial sulfate reduction, is also likely to fractionate $\mathrm{Fe}$ isotopes, 
although the exact magnitude remains unknown. In addition, sorption of $\mathrm{Fe}(\mathrm{II})$ to $\mathrm{Fe}$ (III) oxyhydroxides may result in electron and Fe atom exchanges (Brantley et al., 2004). The accompanying fractionations, however, are small, generally in the range $0.2-0.9 \%$, where sorbed $\mathrm{Fe}(\mathrm{II})$ is enriched in heavy isotopes relative to aqueous Fe(II) (Crosby et al., 2005; Wu et al., 2009; 2010).

Iron isotopes have been applied to infer biogeochemical processes and conditions in a variety of environments, including soils (Wiederhold et al., 2007) and riverine (Bergquist and Boyle, 2006), marine (Fehr et al., 2008) and groundwater (Teutsch et al., 2005) settings. Variations in the Fe isotope compositions of Precambrian marine sedimentary rocks have played a prominent role in discussions on past $\mathrm{Fe}$ cycling in the earth surface environment (e.g., Johnson et al., 2008). Few studies, however, have analyzed $\mathrm{Fe}$ isotope compositions in lakes. The existing studies have generally been carried out in extreme lacustrine environments, such as Fe-rich meromictic lakes (Busigny et al., 2014; Teutsch et al., 2009) and have focused on water column Fe isotope signatures (Busigny et al., 2014; Malinovsky et al., 2005; Teutsch et al., 2009). The observed gradients in isotopic composition of dissolved $\mathrm{Fe}(\mathrm{II})$ across redox transitions in stratified lakes have been interpreted as resulting from either partial oxidation of $\mathrm{Fe}$ (II) (Busigny et al., 2014; Malinovsky et al., 2005) or DIR (Teutsch et al., 2009). A more definite characterization and interpretation of the $\mathrm{Fe}$ isotope signatures of Fe redox processes remain a high priority for the application of $\mathrm{Fe}$ isotopes to modern environments and the rock record.

In this study, in situ measured Fe isotope compositions of pore water and solidbound Fe in sediments of Lake Tantaré, a pristine headwater lake in Québec, Canada, are used to test the transferability of stable $\mathrm{Fe}$ isotope fractionations 
obtained in laboratory studies. The sediments of Lake Tantaré were selected because (1) detailed data on pore water chemistry and solid-phase $\mathrm{Fe}$ geochemistry plus mineralogy are available (Couture et al., 2008; Couture et al., 2010b; Fortin et al., 1993), and (2) the oligotrophic, sulfate-poor conditions in the lake may provide an analog for early Precambrian aquatic environments. The existing data for Lake Tantaré sediments are consistent with an active early diagenetic redox cycling of Fe below the sediment-water interface (SWI). The quantitative interpretation of the pore water and solid-bound Fe depth profiles using reactive transport modeling further indicates that DIR is the main Fe reduction pathway, with only a minor contribution of reductive dissolution of $\mathrm{Fe}$ (III) oxyhydroxides by sulfide (Couture et al., 2010b). Thus, the sediments of Lake Tantare enable the comparative analysis of the isotopic compositions of various $\mathrm{Fe}$ pools in a natural sedimentary environment under well-constrained biogeochemical conditions. 


\section{Method}

\subsection{Site and sampling}

Lake Tantaré $\left(47^{\circ} 04^{\prime} \mathrm{N}, 71^{\circ} 33^{\prime} \mathrm{W}\right)$ is located along the southern fringe of the boreal forest, in a catchment dominated by ferro-humic podzols with mesic drainage conditions that developed on sandy loam till (Payette et al., 1990). The bedrock is granite and gneiss, typical of the Canadian Shield. Lake Tantaré is an acidic ( $\mathrm{pH}$ 5.4-6.0), oligotrophic lake, separated by sills into four basins (Couture et al., 2010b). Sampling was carried out in two basins, Basin A and Basin B, at the westernmost end of the lake. The results presented here are primarily from Basin A, which has a maximum water depth of about $15 \mathrm{~m}$ and permanently oxic bottom waters (> $3.8 \mathrm{mg} \mathrm{O}_{2} \mathrm{~L}^{-1}$ ) (Couture et al., 2008). Basin B has a maximum depth of $21 \mathrm{~m}$ and its bottom waters become anoxic $\left(<0.01 \mathrm{mg} \mathrm{O}_{2} \mathrm{~L}^{-1}\right)$ during late summerearly fall (Couture et al., 2008).

Three acrylic peepers were inserted by divers in the sediments at the deepest point of Basin A in July 2012 and left to equilibrate for 21 days. The chambers of the peepers were spaced equally at $1 \mathrm{~cm}$ intervals. In order to minimize contamination by oxygen, the peepers were prepared according to the procedure developed by Carignan et al. (1994), who carried out their method validation study in Lake Tantaré. The peepers were soaked in an acidic solution for 7 days and in ultra-pure water for another 7 days. The peeper chambers were then filled with ultra-pure water and covered with a $0.2 \mu \mathrm{m}$ pore size membrane (Gelman HT-200 polysulfone) plus a thin plexiglass sheet with holes fitting the cell apertures. The assembled peepers were stored under $\mathrm{N}_{2}$ for two weeks to allow for the complete removal of oxygen, and kept under $\mathrm{N}_{2}$ until deployment.

Upon retrieval, the peepers were raised one by one and immediately sampled. Water from the peeper chambers were collected directly into vials pre-acidified with 
ultra-pure $\mathrm{HCl}$ (Seastar grade). The vials were kept at $4^{\circ} \mathrm{C}$ until analysis. Sediment cores were collected in both basins by divers using butyrate tubes. The cores were immediately sectioned onshore in $0.5 \mathrm{~cm}$ or $1 \mathrm{~cm}$ depth intervals. The sediment was frozen and kept frozen until freeze-drying. The freeze-dried sediment samples were stored under humidity-free conditions prior to the chemical extractions, which were performed within 2 weeks time.

\subsection{Sequential Fe extractions}

Three-step sequential acid extractions were performed on the sediment samples following the method of Tangalos et al. (2010). Extractions 1 and 2 were carried out in an anaerobic chamber. All extraction solutions were deoxygenated with $\mathrm{O}_{2}$-free $\mathrm{N}_{2}$ gas. In extraction $1,5 \mathrm{~mL}$ of $0.1 \mathrm{M} \mathrm{HCl}$ was added to $10 \mathrm{mg}$ freezedried sediment. The mixture was left to react for 1 hour, then centrifuged at 4800 rpm for 10 minutes. The supernatant was filtered through a $0.2 \mu \mathrm{m}$ pore size syringe filter (extract 1). The remaining solid was mixed with $5 \mathrm{~mL}$ of $0.5 \mathrm{M} \mathrm{HCl}$. After 24 hours, the mixture was centrifuged (4800 rpm for 10 minutes) and the supernatant was filtered $(0.2 \mu \mathrm{m}$ pore size syringe filter) producing extract 2 . The remaining solid was mixed with $5 \mathrm{~mL}$ of $7 \mathrm{M} \mathrm{HCl}$ and then placed in a $70^{\circ} \mathrm{C}$ oven for 72 hours. After that, the mixture solution was centrifuged and the supernatant was filtered as described before, yielding extract 3 .

Based on previous work, extraction 1 removes sorbed $\mathrm{Fe}(\mathrm{II})$ and the most reactive fraction of amorphous $\mathrm{Fe}(\mathrm{III})$ oxyhydroxides (Tangalos et al., 2010); extraction 2 removes amorphous Fe(III) oxyhydroxides and residual solid-phase $\mathrm{Fe}$ (II) such as FeS and some silicate Fe that cannot be extracted by $0.1 \mathrm{M} \mathrm{HCl}$ (Severmann et al., 2006; Tangalos et al., 2010). We refer to the Fe(II) in extract 2 
as "tightly-bound $\mathrm{Fe}(\mathrm{II})$ ". Both $0.1 \mathrm{M}$ and $0.5 \mathrm{M} \mathrm{HCl}$ mainly extract amorphous to poorly-crystalline Fe phases. Crystalline Fe phases, such as hematite, goethite, and magnetite, but not pyrite and Fe silicates, are extracted by $7 \mathrm{M} \mathrm{HCl}$ (extraction 3) (Severmann et al., 2006; Tangalos et al., 2010).

\subsection{Iron concentrations}

\subsubsection{Standard curve preparation}

There is a linear relation between absorbance and concentration of substance according to Beer-Lambert law (Stookey, 1970). Standard curve analysis was to determine this linear relation by using Ferrozine Method. $\mathrm{FeCl}_{2}$ standard solutions were prepared first. Because pore water samples and sediment samples had significantly different iron concentrations, two different sets of $\mathrm{FeCl}_{2}$ standard solutions were prepared. The $\mathrm{Fe}(\mathrm{II})$ concentrations of $\mathrm{FeCl}_{2}$ standard solution for pore water samples ranged from $10 \mu \mathrm{M}$ to $110 \mu \mathrm{M}$, while those for sediment samples ranged from $10 \mu \mathrm{M}$ to $640 \mu \mathrm{M}$. Standard solutions were prepared in $0.5 \mathrm{M} \mathrm{HCl}$. In order to analyze the concentration of total $\mathrm{Fe}(\mathrm{Fe}(\mathrm{tot}))$ for $7 \mathrm{M} \mathrm{HCl}$ extraction solution, a $\mathrm{FeCl}_{3}$ standard solution was prepared in $7 \mathrm{M} \mathrm{HCl}$ with the concentrations ranging from $8 \mu \mathrm{M}$ to $850 \mu \mathrm{M}$. For the standard curve analysis, $1 \mathrm{~mL}$ ferrozine solution ( $1 \mathrm{~g} / \mathrm{L}$ ferrozine, $12 \mathrm{~g} / \mathrm{L}$ HEPES buffer, and $\mathrm{pH}$ 6) was added to $38 \mu \mathrm{L}$ standard solutions. The absorbance was measured by using UV-vis. Since the $\mathrm{FeCl}_{3}$ standard solutions needed to be reduced to $\mathrm{Fe}$ (II) before reacting with ferrozine, $100 \mu \mathrm{L} 10 \%$ hydroxylamine hydrochloride was added to 38 $\mu \mathrm{L} \mathrm{FeCl}{ }_{3}$ standard solution (with $1 \mathrm{~mL}$ ferrozine) and the mixture solution was sit for $\sim 12$ hours before measuring the absorbance. 


\subsubsection{Ferrous and ferric iron concentration analysis for pore water samples}

The measurement for ferrous and ferric concentrations in pore water samples was done using the method similar to the standard curve analysis: $1 \mathrm{~mL}$ ferrozine solution ( $1 \mathrm{~g} / \mathrm{L}$ ferrozine, $12 \mathrm{~g} / \mathrm{L}$ HEPES buffer, and $\mathrm{pH} 6$ ) was added to $38 \mu \mathrm{L}$ sample to determine the concentration of $\mathrm{Fe}(\mathrm{II})$ by using UV-vis. The absorbance of each pore water sample was recorded. By using absorbance and the equation derived from standard curve analysis, the concentration of $\mathrm{Fe}(\mathrm{II})$ was calculated. For the concentration of $\mathrm{Fe}(\mathrm{tot}), 1 \mathrm{~mL}$ ferrozine solution and $100 \mu \mathrm{L} 10 \%$ hydroxylamine hydrochloride was added to $38 \mu \mathrm{L}$ sample and placed overnight, then the absorbance of each pore water sample was measured by UV-vis again. By using absorbance and the equation derived from standard curve analysis, the concentration of $\mathrm{Fe}$ (tot) was calculated. The concentration of $\mathrm{Fe}$ (III) was calculated by $\mathrm{C}_{\mathrm{Fe} \text { (tot) }}$ minus $\mathrm{C}_{\mathrm{Fe} \text { (II) }}\left(\mathrm{C}_{\mathrm{Fe} \text { (tot) }}\right.$ was the concentration of total iron, $\mathrm{C}_{\mathrm{Fe} \text { (II) }}$ was the concentration of ferrous iron).

\subsubsection{Ferrous and ferric iron concentration analysis for sediment samples}

Iron concentrations in the solutions from the sediment extractions (i.e., extracts 1, 2 and 3) were determined spectrophotometrically by the Ferrozine method (Stookey, 1970; Viollier et al., 2000). The total Fe (Fe(tot)) concentration of a sample was determined after adding $10 \%$ hydroxylamine $\mathrm{HCl}$, which reduces any soluble $\mathrm{Fe}(\mathrm{III})$ present in the sample. The concentration of $\mathrm{Fe}(\mathrm{III})$ in the sample was then calculated as the difference between the concentration of $\mathrm{Fe}$ (tot) and that of $\mathrm{Fe}(\mathrm{II})$ measured before adding hydroxylamine. A reagent blank was prepared by adding $10 \%$ hydroxylamine $\mathrm{HCl}$ to a $0.5 \mathrm{M} \mathrm{HCl}$ solution. The reagent blank was subtracted from the sample absorbance when calculating the Fe concentration from the standard curve. The detection limit of $0.5 \square \mathrm{M}$ was estimated based on the 
minimum detectable change in absorbance in a $1 \mathrm{~cm}$ cell; it is comparable to the $0.3 \mu \mathrm{M}$ detection limit reported by Viollier et al. (2000).

\subsection{Iron isotope analyses}

Prior to the isotope analyses, $\mathrm{Fe}$ in the samples was purified with ion-exchange chromatography following the procedures given in Beard et al. (2003). In details, enough volume of sample (containing 20-50 $\mu$ g of iron) was added into preleached (using $1 \mathrm{X} 8 \mathrm{M} \mathrm{HCl}$ ) labeled Teflon beakers. The samples were dried out in clean room. Then $0.5 \mathrm{~mL} 2 \times 7 \mathrm{M} \mathrm{HCl}$ was added into Teflon beakers and was dried out. The samples are preserved in closed beaker for overnight. The samples were loaded to column (containing resin in $7 \mathrm{M} \mathrm{HCl}$ matrix) for $1^{\text {st }}$ pass. After that, 1.2 $\mathrm{mL} 2 \mathrm{X} 7 \mathrm{M} \mathrm{HCl}$ was passed through the resin to get rid of other cations rather than Fe. The sample was collected in preleached (using $1 \mathrm{X} 8 \mathrm{M} \mathrm{HCl}$ ) labeled Teflon beakers by passing $2.1 \mathrm{~mL} 2 \mathrm{X} 0.5 \mathrm{M} \mathrm{HCl}$. The samples were dried out and went through $2^{\text {nd }}$ pass that is similar with $1^{\text {st }}$ pass but $4.7 \mathrm{~mL} 2 \mathrm{X} 7 \mathrm{M} \mathrm{HCl}$ instead of 1.2 $\mathrm{mL} 2 \mathrm{X} 7 \mathrm{M} \mathrm{HCl}$. After dried out, ultra pure $\mathrm{HNO}_{3}$ was added to sample and then dried out again. The final sample was preserved in $2 \% \mathrm{HNO}_{3}$ matrix and the iron concentrations of samples were $25 \mathrm{ppm}$. To test that chemical separation produces accurate results, 17 test solutions were prepared by adding 2.25 to $18.6 \mu \mathrm{g}$ of HPS (high purity standard®) Fe (in-house standard) to synthetic solutions. The test solutions had concentrations of major ions $\left(\mathrm{Ca}^{2+}, \mathrm{Mg}^{2+}, \mathrm{K}^{+}, \mathrm{Na}^{+}, \mathrm{HCO}_{3}{ }^{-}, \mathrm{Cl}^{-}, \mathrm{SO}_{4}{ }^{2-}\right)$ that mimic those found in the lake's pore waters (Couture et al., 2010a).

Iron isotope compositions of pore water samples, acid extractions, and test solutions were measured by a multicollector, inductively coupled plasma mass spectrometer (MC-ICP-MS; Micromass IsoProbe) at the University of Wisconsin- 
Madison, following established protocols (Beard et al., 2003). All Fe isotope data are reported as $\delta^{56} \mathrm{Fe}$ values in units of per mil $(\%)$ :

$\delta^{56} \mathrm{Fe}=\left[\left({ }^{56} \mathrm{Fe} /{ }^{54} \mathrm{Fe}\right.\right.$ sample $\left.) /\left({ }^{56} \mathrm{Fe} /{ }^{54} \mathrm{Fe}_{\text {standard }}\right)-1\right] \times 10^{3}$,

where ${ }^{56} \mathrm{Fe} /{ }^{54} \mathrm{Fe}$ standard is the average of igneous rocks $\left(\delta^{56} \mathrm{Fe}=0.0 \pm 0.05 \%\right.$, Beard et al., 2003). Measured external precision for $\delta^{56} \mathrm{Fe}$ was $0.04 \%$ (1б; $\left.\mathrm{n}=108\right)$. The average $\delta^{56} \mathrm{Fe}$ value of the test solutions was $0.49 \pm 0.05 \%(1 \sigma ; n=17)$, which is identical to the isotope composition measured for the pure HPS Fe solutions $\left(\delta^{56} \mathrm{Fe}=0.52 \pm 0.07 \% ; 1 \sigma ; n=23\right)$. The measured $\mathrm{Fe}$ isotope composition of the IRMM-019 Fe isotope standard was $-0.07 \pm 0.06 \%$ ( $1 \sigma ; n=29)$, which lies within error of the long-term standard value of $-0.09 \%$ relative to average igneous rocks used in the lab in Madison (Beard et al., 2003). 


\section{Results and discussion}

\subsection{Dissolved Fe}

Total dissolved Fe concentrations increase from values around $4 \mu \mathrm{M}$ in the overlying water to $\sim 26 \mu \mathrm{M}$ at a depth of $2.5 \mathrm{~cm}$ below the sediment-water interface (SWI), followed by a gentle decline at greater depths (Fig. 1a; Table A.1). On average, $\mathrm{Fe}(\mathrm{III})$ makes up $83 \%$ of total dissolved $\mathrm{Fe}$ in the bottom water. Below the oxygen penetration depth, which is on the order of a few $\mathrm{mm}$ (Couture et al., 2010b), $\mathrm{Fe}(\mathrm{III})$ still represents on average $45 \%$ of total pore water $\mathrm{Fe}$. The relatively high concentrations of $\mathrm{Fe}(\mathrm{III})$ are unexpected, as $\mathrm{Fe}$ (III) should have low solubility in the oxygenated bottom waters (Liu and Millero, 2002; Millero, 1998), while the reduction to $\mathrm{Fe}(\mathrm{II})$ should result in low dissolved $\mathrm{Fe}$ (III) concentrations below the oxygen penetration depth.

The reason for the relatively high abundance of dissolved $\mathrm{Fe}(\mathrm{III})$ in the pore waters of Lake Tantaré sediments could not be determined with certainty. Although we cannot exclude that a fraction of dissolved $\mathrm{Fe}(\mathrm{II})$ strongly bound to organic matter may have escaped the Ferrozine extraction, resulting in an underestimation of aqueous $\mathrm{Fe}(\mathrm{II})$ concentrations, we do not believe this to be the case, because Ferrozine has been demonstrated to be able to fully recover $\mathrm{Fe}(\mathrm{II})$ bound to organic matter, even in settings with higher organic content than the sediments in this study (Pullin and Cabaniss, 2001; Viollier et al., 2000). More likely, the high dissolved $\mathrm{Fe}$ (III) concentrations are due to oxidation artifacts, the formation of strong organic complexes, the presence of $\mathrm{Fe}$ (III) colloids, or some combination of these. 

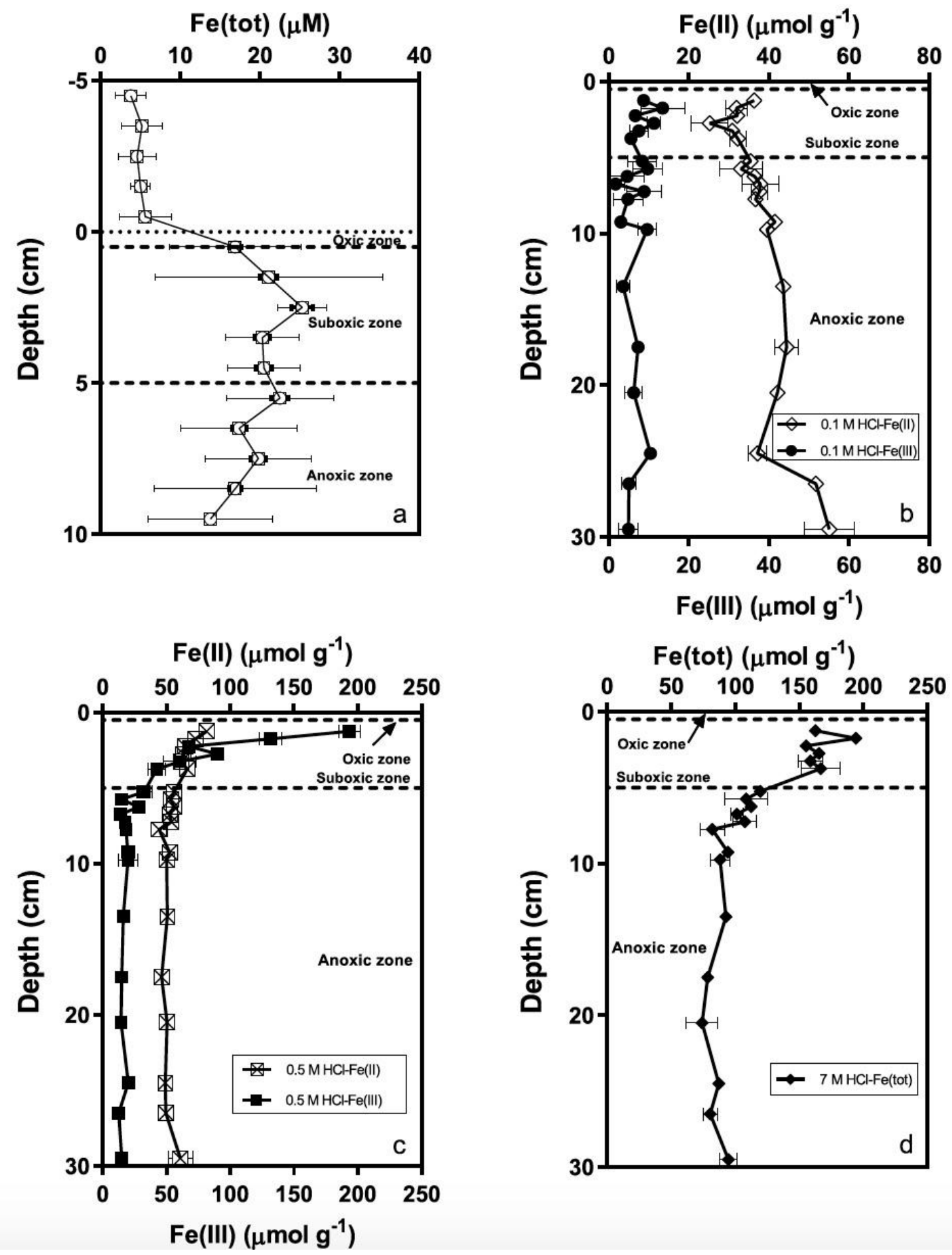

Fig. 1. Depth profiles of (a) the total pore water Fe concentration, and (b-d) the solid sediment Fepools derived from the sequential acid extractions. Thin line error bars in panel (a) indicate standard deviations for triplicate measurements of three peepers, while in panels $(b-d)$ they indicate the range for duplicate sediment samples. Thick line error bars correspond to the $5 \%$ error from the Ferrozine analysis. Zero depth corresponds to the sediment-water interface(SWI). See text for the definition of the redox zones in the sediment. 
While precautions were taken to minimize contamination by oxygen (see Sections 2.1, 2.2 and 2.3), part of the Fe(III) observed in the pore waters below the oxygen penetration depth may reflect oxidation of $\mathrm{Fe}(\mathrm{II})$ originally present in the samples. In section 3.3, we assess the uncertainty introduced by potential oxidation artifacts on the estimated Fe isotope fractionations. Nonetheless, some of the pore water Fe(III) probably represents true oxidized Fe(III) stabilized by organic complexation. Recently, Beckler et al. (2015) reported that soluble Fe(III) (up to millimolar level) dominate dissolved Fe in the suboxic pore waters at the lowsalinity end of an estuary. These authors attribute their observation to nonreductive dissolution of $\mathrm{Fe}(\mathrm{III})$ hydroxides and oxidation of organic-Fe(II) complexes by Fe(III) oxyhydroxides.

Oxygen-containing functional groups, such as hydroxyl, carboxyl, phenol and carbonyl, of natural dissolved organic matter are able to bind Fe (Catrouillet et al., 2014). Complexation of $\mathrm{Fe}(\mathrm{III})$ by dissolved organic matter enhances the solubility of $\mathrm{Fe}(\mathrm{III})$ in oxygenated waters, while high dissolved $\mathrm{Fe}(\mathrm{III})$ concentrations in anoxic pore waters may be the product of ligand-promoted dissolution of solidphase $\mathrm{Fe}(\mathrm{III})$. As shown in Pullin and Cabaniss (2003), at pH 6 to 8, complexation of $\mathrm{Fe}(\mathrm{II})$ by fulvic acid accelerates the overall oxidation rate of $\mathrm{Fe}(\mathrm{II})$ and promotes $\mathrm{Fe}(\mathrm{III})$ colloid formation, whereas Fe(III)-fulvic acid complexes stabilize Fe(III) in the aqueous phase. Therefore, it is possible that the observed dissolved $\mathrm{Fe}(\mathrm{III})$ can be explained in part by colloid formation, in the presence of $\mathrm{O}_{2}$ and promoted by $\mathrm{Fe}$ (II)-organic matter complexation, and in part by enhanced non-reductive dissolution and stabilization due to $\mathrm{Fe}(\mathrm{III})$-organic matter complexation.

The build-up of pore water Fe(II) below the SWI is consistent with Fe redox cycling within the upper centimeters of the sediments, as proposed in previous 
studies conducted in Basin A (Chappaz et al., 2008; Couture et al., 2010b; Feyte et al., 2010; Feyte et al., 2012). Iron(III) oxyhydroxides undergo reductive dissolution below the oxygen penetration depth, releasing $\mathrm{Fe}(\mathrm{II})$ to the pore water. The latter partly diffuses upward and is reoxidized at or just above the SWI. Burial of the resulting diagenetic $\mathrm{Fe}(\mathrm{III})$ oxyhydroxides, together with $\mathrm{Fe}(\mathrm{III})$ oxyhydroxides deposited from the water column, then maintains the redox cycle. The SWI therefore works as a barrier to the upward flux of $\mathrm{Fe}(\mathrm{II})$, which in turn limits the transfer of many elements from the sediments to the water column. This scenario is supported by the solid-phase Fe data discussed in the next section.

\subsection{Solid-phase Fe}

The redox zones indicated on Figs. 1 and 2 are based on published geochemical depth distributions in the sediments of Lake Tantaré. Briefly, the oxic, suboxic, and anoxic zones are defined by the depth of dissolved oxygen penetration (0.3-0.5 cm, Couture et al., 2010b), the depth of maximum sedimentary rhenium enrichment $(4-8 \mathrm{~cm}$, Chappaz et al., 2008) and the depth of maximum dissolved sulfide concentrations (6-10 cm, Couture et al., 2010a), respectively. The topmost layer of sediment in the perennially oxygenated Basin A of Lake Tantaré is enriched in $\mathrm{Fe}$ (III) oxyhydroxides (up to $1 \mathrm{mmol} \mathrm{Fe} \mathrm{g}^{-1}$, Couture et al., 2010b), which consist mainly of poorly crystalline ferrihydrite, lepidocrocite and goethite as shown by Fortin et al. (1993). The concurrent decreases with depth of the concentrations of $\mathrm{Fe}(\mathrm{III})$ oxyhydroxides and labile organic matter has been attributed to organic carbon oxidation coupled to DIR (Couture et al., 2010b), a process that has been shown to induce profound changes in the reactivity of both organic matter and Fe oxyhydroxides (Benner et al., 2002). 
Here, the solid-phase Fe distributions in the sediments are further characterized using sequential acid extractions. The results for Basin A are shown in Figs. 1b-d (for Basin B, see Appendices). As can be seen in Fig. 1b, extract 1 $(0.1 \mathrm{M} \mathrm{HCl})$ yields a generally increasing trend of sorbed $\mathrm{Fe}(\mathrm{II})$ with depth (range: 25-55 $\mu \mathrm{mol} \mathrm{g}{ }^{-1}$ ). A sharp drop with depth is observed for the amorphous and poorly crystalline $\mathrm{Fe}(\mathrm{III})$ oxyhydroxide concentrations extracted in $0.5 \mathrm{M} \mathrm{HCl}$ (range: 13$193 \mu \mathrm{mol} \mathrm{g}^{-1}$, Fig. 1C). In extract 2, Fe(III) dominates in the uppermost sediment, while $\mathrm{Fe}$ (II) becomes more abundant at greater depths. The total extractable $\mathrm{Fe}$ concentrations in sediments of Basin $\mathrm{A}$ ( $\mathrm{Fe}_{\text {sum }}=$ sum of the three acid extractions) display a decreasing trend over the upper $10 \mathrm{~cm}$ of sediment, while the fraction of $\mathrm{Fe}$ (II) in total extractable Fe continuously increases with depth, from about $25 \%$ to $50 \%$ (Fig. 2).

Together, the pore water and solid-phase Fe distributions are consistent with active cycling of $\mathrm{Fe}$ in the sediments (Couture et al., 2010b; Feyte et al., 2010; Fortin et al., 1993). The drop with depth of the Fe(III) concentrations extracted in $0.5 \mathrm{M} \mathrm{HCl}$ from the SWI downwards until $\sim 6 \mathrm{~cm}$ depth is explained by the reductive and non-reductive dissolution of reactive $\mathrm{Fe}(\mathrm{III})$ oxyhydroxides (Couture et al., 2010b). A fraction of the resulting dissolved Fe(II) diffuses upward where it is rapidly reoxidized at the SWI, while the remainder is retained in the reducing sediment as solid-bound $\mathrm{Fe}(\mathrm{II})$. Part of the dissolved $\mathrm{Fe}(\mathrm{III})$ produced by nonreductive dissolution of reactive $\mathrm{Fe}(\mathrm{III})$ oxyhydroxides likely escapes to the overlying water, either as $\mathrm{Fe}$ (III)-organic complexes or $\mathrm{Fe}(\mathrm{III})$ colloids, while part is ultimately reduced and buried as solid-bound $\mathrm{Fe}(\mathrm{II})$. 


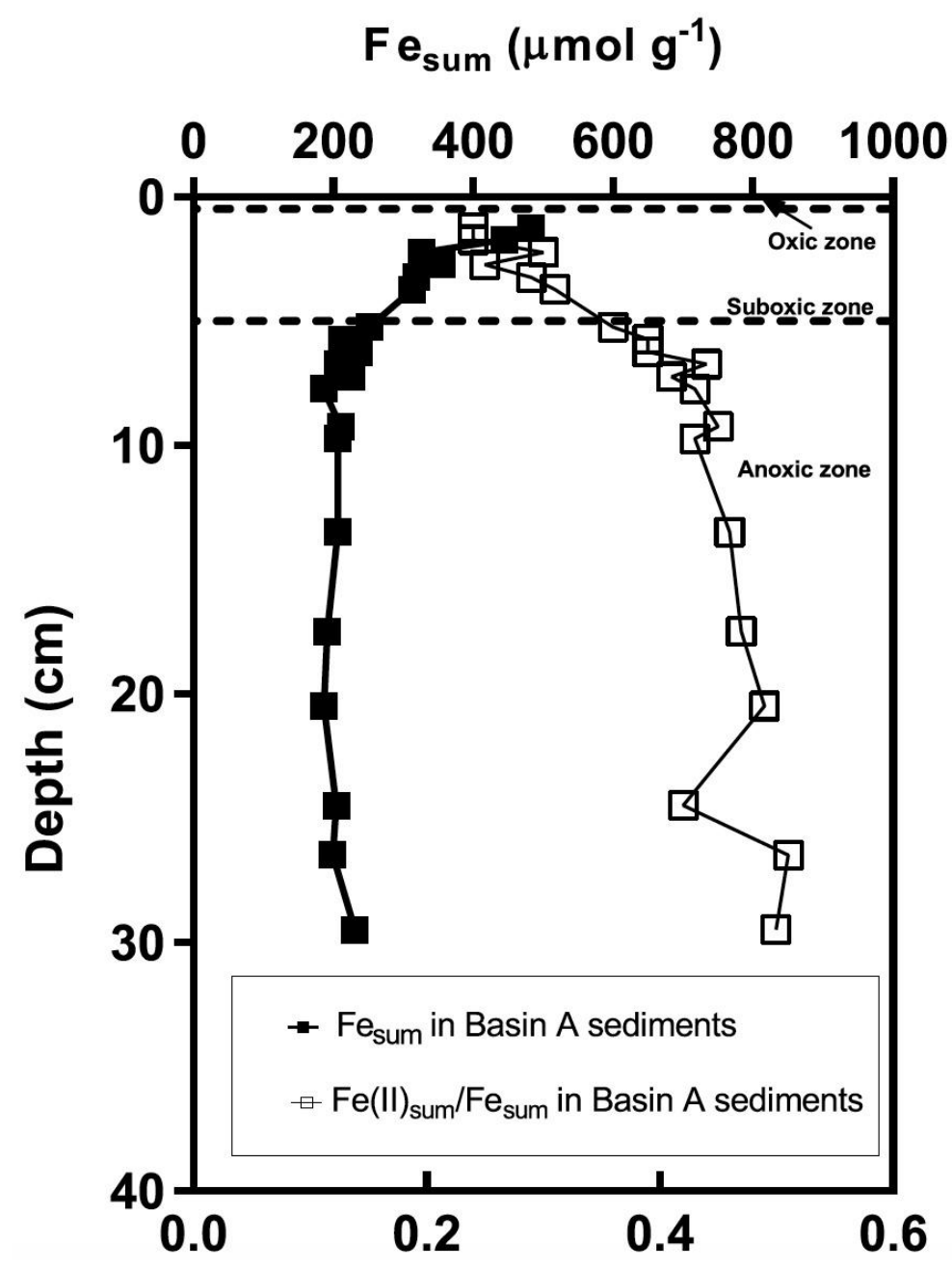

Fig. 2. Depth profiles of the concentration of total $\mathrm{Fe}\left(\mathrm{Fe}_{\text {sum }}\right)$ and $\mathrm{Fe}(\mathrm{II}) /$ total $\mathrm{Fe}$ ratio $\left(\mathrm{Fe}(\mathrm{II})_{\text {sum }} / \mathrm{Fe}_{\text {sum }}\right)$ for bulk sediments in Basin A. Error bars indicate errors for two duplicate sediment samples. Errors are smaller than symbol size when not shown.

Results from a multi-component reactive transport model indicate that, primarily because of the low abundance of sulfate in Lake Tantaré, the reduction of the reactive $\mathrm{Fe}(\mathrm{III})$ oxyhydroxide pool in the upper $5-6 \mathrm{~cm}$ of sediment is mostly due to DIR (Couture et al., 2010b). Reaction with $\mathrm{H}_{2} \mathrm{~S}$ produced by microbial sulfate reduction accounts for only about $10 \%$ of total $\mathrm{Fe}(\mathrm{III})$ oxyhydroxide reduction, which is consistent with the absence of a significant build-up of solidphase Fe(II) below the oxygen penetration depth (Figs. 1b and 1c). Note, however, that in contrast to earlier work (Couture et al., 2010b), our pore water results suggest that non-reductive $\mathrm{Fe}(\mathrm{III})$ oxyhydroxide dissolution may represent a more 
important pathway in the early diagenetic cycling of $\mathrm{Fe}$ in sediments of Basin $\mathrm{A}$ than recognized previously.

\subsection{Iron isotopes}

The different Fe pools measured in the sediments of Basin A (perennially oxygenated) and Basin B (seasonally anoxic) exhibit distinct isotopic compositions. The most negative $\delta^{56} \mathrm{Fe}$ values are observed for the pore waters of Basin $\mathrm{A}$ sediments: $\delta^{56} \mathrm{Fe}$ values range from -2.10 to $-0.85 \%$ (average: $-1.33 \pm 0.42 \%$ ) (Fig. 3; Tables A.4). The $\delta^{56} \mathrm{Fe}$ values of $0.1 \mathrm{M} \mathrm{HCl}$-extractable Fe (extract 1) vary from -1.21 to $-0.53 \%$ (average: $-0.92 \pm 0.18 \%$ ) in Basin $A$, and from -0.57 to 0.19\%o (average: $-0.34 \pm 0.16 \%$ ) in Basin B (Fig. 3; Tables A.5 and A.6). The $0.5 \mathrm{M}$ $\mathrm{HCl}$-extractable $\mathrm{Fe}$ (extract 2) exhibits even more positive $\delta^{56} \mathrm{Fe}$ values, ranging from 0.23 to $0.55 \%$ o (average: $0.42 \pm 0.08 \%$ ) in Basin $A$ and from 0.23 to $0.68 \%$ o (average: $0.43 \pm 0.12 \%$ ) in Basin $\mathrm{B}$. The $7 \mathrm{M} \mathrm{HCl}$-extractable $\mathrm{Fe}$ (extract 3 ) yields

the heaviest isotope compositions, with $\delta^{56} \mathrm{Fe}$ values between 0.26 and $0.85 \%$ (average: $0.56 \pm 0.17 \%$ ) in Basin $A$ and between 0.62 and $0.94 \%$ (average: $0.82 \pm 0.18 \%$ ) in Basin B.

The pore waters, as well as extractions 1 and 2, yield mixtures of both $\mathrm{Fe}(\mathrm{II})$ and $\mathrm{Fe}(\mathrm{III})$ (Tables A.1-A.3). To separate the total Fe isotope compositions measured on the aqueous samples into the contributions from $\mathrm{Fe}(\mathrm{II})$ and $\mathrm{Fe}(\mathrm{III})$, we rely on the following two assumptions. (1) The $\mathrm{Fe}(\mathrm{III})$ species in the different $\mathrm{HCl}$ extractions have the same Fe isotope compositions. This is supported by close resemblance of the measured Fe isotope compositions of extract 2 and extract 3 for Basin A (Fig. 3; Table A.5), as well as by previous studies that show no isotopic fractionation during partial dissolution of solid-phase $\mathrm{Fe}$ by $\mathrm{HCl}$ (Beard and 
Johnson, 2004; Skulan et al., 2002; Wiederhold et al., 2006). Consequently, we postulate that the small differences in $\delta^{56} \mathrm{Fe}$ values for extractions 2 and 3 are due to the $\mathrm{Fe}(\mathrm{II})$ present in extract 2. (2) Pore water $\mathrm{Fe}(\mathrm{III})$ has the same isotopic composition as that of solid-phase $\mathrm{Fe}$ (III) oxyhydroxides. The $\mathrm{Fe}$ isotope composition of pore water $\mathrm{Fe}(\mathrm{III})$ can then be derived directly from the $\delta^{56} \mathrm{Fe}$ value of extract 3. A major source of uncertainty with this assumption is the current limited knowledge about potential isotope fractionations associated with the ligandpromoted dissolution of $\mathrm{Fe}(\mathrm{III})$ oxyhydroxides and complexation of $\mathrm{Fe}(\mathrm{III})$ by dissolved organic matter. A few studies using experimental approaches (Dideriksen et al., 2008; Morgan et al., 2011) and theoretical calculations (Domagal-Goldman and Kubicki, 2008; Domagal-Goldman et al., 2009) imply that

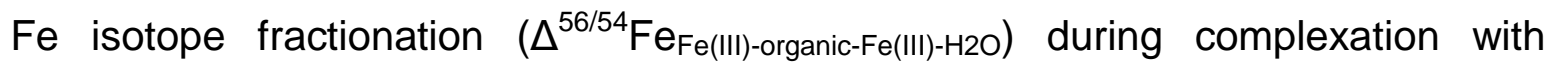
organic ligands should be within $1 \%$.
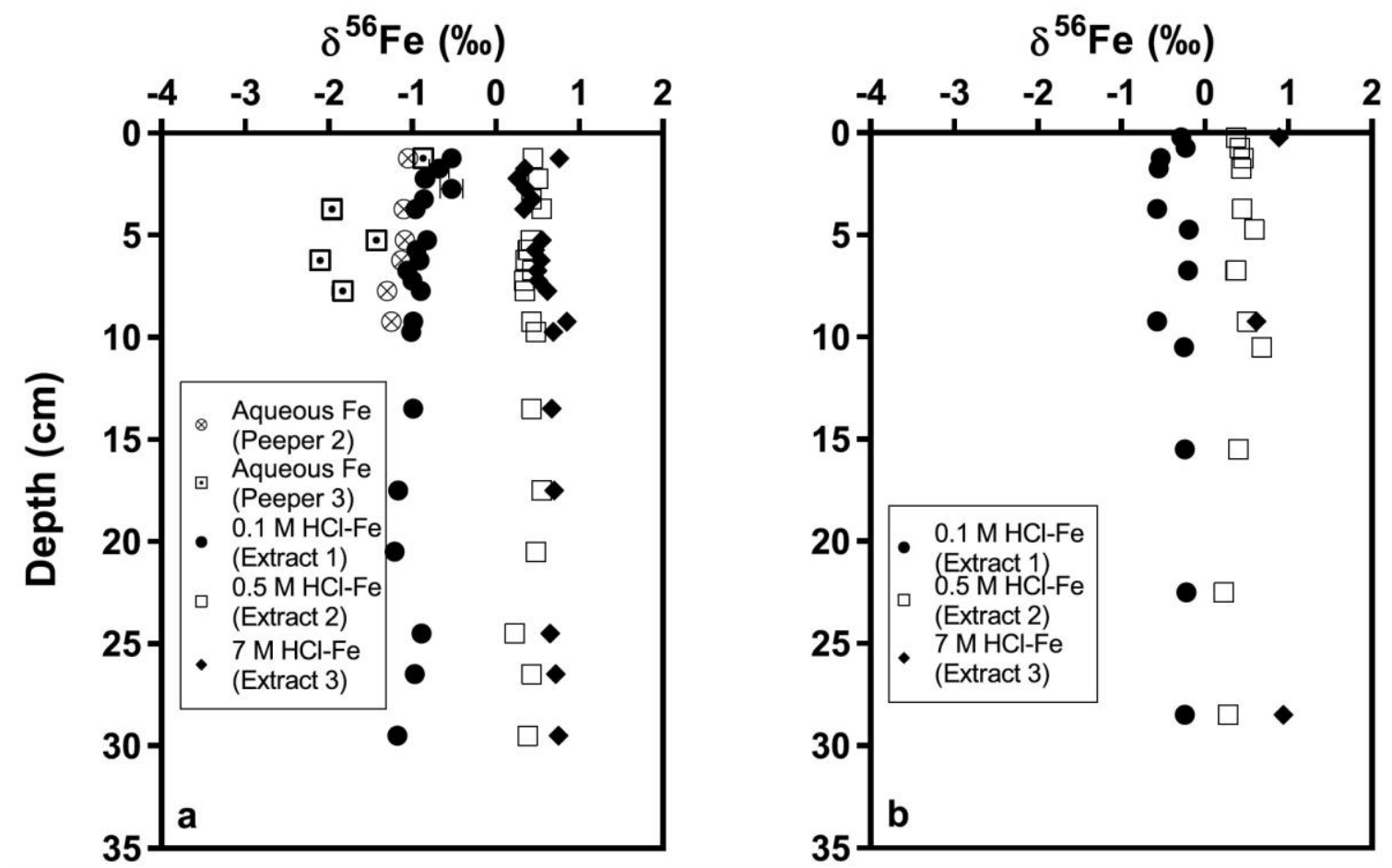

Fig. 3. Measured iron isotope compositions for pore water and three sediment extractions( which is a mixture of $\mathrm{Fe}(\mathrm{II})$ and $\mathrm{Fe}(\mathrm{III})$ in Basin $\mathrm{A}$ (panel a) and only three sediment extractions in Basin $\mathrm{B}$ (panel b). Error bars are not shown because they are much smaller than the symbol sizes. 
With the above two assumptions, it is possible to estimate the isotopic compositions of aqueous, sorbed, and tightly-bound $\mathrm{Fe}(\mathrm{II})$, based on the $\mathrm{Fe}(\mathrm{II}): \mathrm{Fe}(\mathrm{III})$ ratios measured in the pore water samples, and in extracts 1 and 2 (Fig. A.3; Tables A.7 and A.8; see detailed calculations in Appendices). The resulting isotopic compositions of the pore water and $\mathrm{HCl}$ extractable $\mathrm{Fe}$ sediment pools are compared in Fig. 4 . The $\delta^{56} \mathrm{Fe}$ values are as follows: $-2.12 \pm 0.60 \%$ for pore water $\mathrm{Fe}(\mathrm{II})$ of Basin $\mathrm{A} ;-1.25 \pm 0.20 \%$ for sorbed $\mathrm{Fe}(\mathrm{II})$ in Basin $\mathrm{A}$ and $1.06 \pm 0.27 \%$ in Basin $\mathrm{B} ; 0.34 \pm 0.22 \%$ for tightly-bound $\mathrm{Fe}(\mathrm{II})$ in Basin $\mathrm{A}$ and $0.09 \pm 0.32 \%$ in Basin $\mathrm{B}$; $0.56 \pm 0.17 \%$ for $\mathrm{Fe}(\mathrm{III})$ oxyhydroxides in Basin $\mathrm{A}$ and $0.82 \pm 0.18 \%$ in Basin B. The largest propagated error is associated with pore water $\mathrm{Fe}(\mathrm{II})$ as many of the concentrations measured were close to the detection limit of $0.5 \square \mathrm{M}$ (Table A.7). Further note that the relatively high $\delta^{56} \mathrm{Fe}$ values inferred for the $\mathrm{Fe}$ (III) oxyhydroxides are largely balanced by the isotopically light sorbed $\mathrm{Fe}(\mathrm{II})$ extracted by $0.1 \mathrm{M} \mathrm{HCl}$ that is retained in the sediments (Fig. A.3. and Tables A.9 and A.10).

The greatest difference in $\delta^{56} \mathrm{Fe}$ values is observed between pore water $\mathrm{Fe}(\mathrm{II})$ and the sediment Fe(III) oxyhydroxide pool (Fig. 4). We speculate that the isotopically light pore water $\mathrm{Fe}(\mathrm{II})$ reflects the activity of the resident dissimilatory iron-reducing microorganisms, which have been proposed to be responsible for most of the $\mathrm{Fe}(\mathrm{III})$ reduction in sediments of Basin A (Couture et al., 2010b). Abiotic oxidation of $\mathrm{Fe}(\mathrm{II})$ by $\mathrm{O}_{2}$ at the sediment-water interface is less likely to contribute significantly to the observed negative isotopic compositions of pore water and sorbed $\mathrm{Fe}(\mathrm{II})$, given the very limited $\mathrm{O}_{2}$ penetration depth of only a few $\mathrm{mm}$, while negative $\delta^{56} \mathrm{Fe}$ values are observed for pore water $\mathrm{Fe}(\mathrm{II})$ across the entire depth interval over which DIR takes place. 
The negative $\delta^{56} \mathrm{Fe}$ values for pore water from Basin A (average: $2.12 \pm 0.60 \%$ ) fall within the range observed in previous experimental studies, which have yielded $\delta^{56} \mathrm{Fe}$ values of aqueous $\mathrm{Fe}(\mathrm{II})$ produced by DIR in the range of -3 to $-1 \%$, depending on the different proportions of aqueous $\mathrm{Fe}(\mathrm{II})$, sorbed $\mathrm{Fe}(\mathrm{II})$, and reactive $\mathrm{Fe}(\mathrm{III})$ (Crosby et al., 2007). Using the Basin A data, we obtain an apparent ${ }^{56} \mathrm{Fe} /{ }^{54} \mathrm{Fe}$ fractionation of $2.6 \pm 0.5 \%$ for the reduction of $\mathrm{Fe}(\mathrm{III})$ oxyhydroxides to aqueous $\mathrm{Fe}(\mathrm{II})$, which is in line with the fractionations measured in previous studies using model dissimilatory iron-reducing microorganisms (i.e., Geobacter sulfurreducens, Shewanella putrefaciens) and pure Fe(III) minerals, such as hematite and goethite (Crosby et al., 2005; Johnson et al., 2005; Wu et al., 2009).

To account for the possible oxidation of part of the pore water $\mathrm{Fe}(\mathrm{II})$ during sampling and processing, we calculate an absolute lower limit for the ${ }^{56} \mathrm{Fe} /{ }^{54} \mathrm{Fe}$ fractionation associated with reduction of $\mathrm{Fe}(\mathrm{III})$ oxyhydroxides by assuming that the original pore water $\mathrm{Fe}$ in Basin A was entirely present as $\mathrm{Fe}(\mathrm{II})$. In that case, the isotope composition of the original $\mathrm{Fe}(\mathrm{II})$ would be equal to the measured $\delta^{56} \mathrm{Fe}$ of pore water (average: $-1.33 \pm 0.42 \%$ ). In addition, if oxidation artificially increased solid-state $\mathrm{Fe}(\mathrm{III})$, then the true $\delta^{56} \mathrm{Fe}$ of the $\mathrm{Fe}(\mathrm{III})$ oxyhydroxide pool in the sediments of Basin A would be heavier than $0.56 \pm 0.17 \%$. Thus, by combining the highest possible pore water $\delta^{56} \mathrm{Fe}$ value with the lowest possible $\delta^{56} \mathrm{Fe}$ value of the $\mathrm{Fe}$ (III) oxyhydroxides, we obtain a minimum value of $-1.4 \pm 0.4 \%$ o for the apparent ${ }^{56} \mathrm{Fe} /{ }^{54} \mathrm{Fe}$ fractionation between pore water $\mathrm{Fe}(\mathrm{II})$ and $\mathrm{Fe}(\mathrm{III})$ oxyhydroxides, that is, a value closer to the fractionation measured in the laboratory for dissimilatory reduction of ferrihydrite (Beard et al., 1999). 

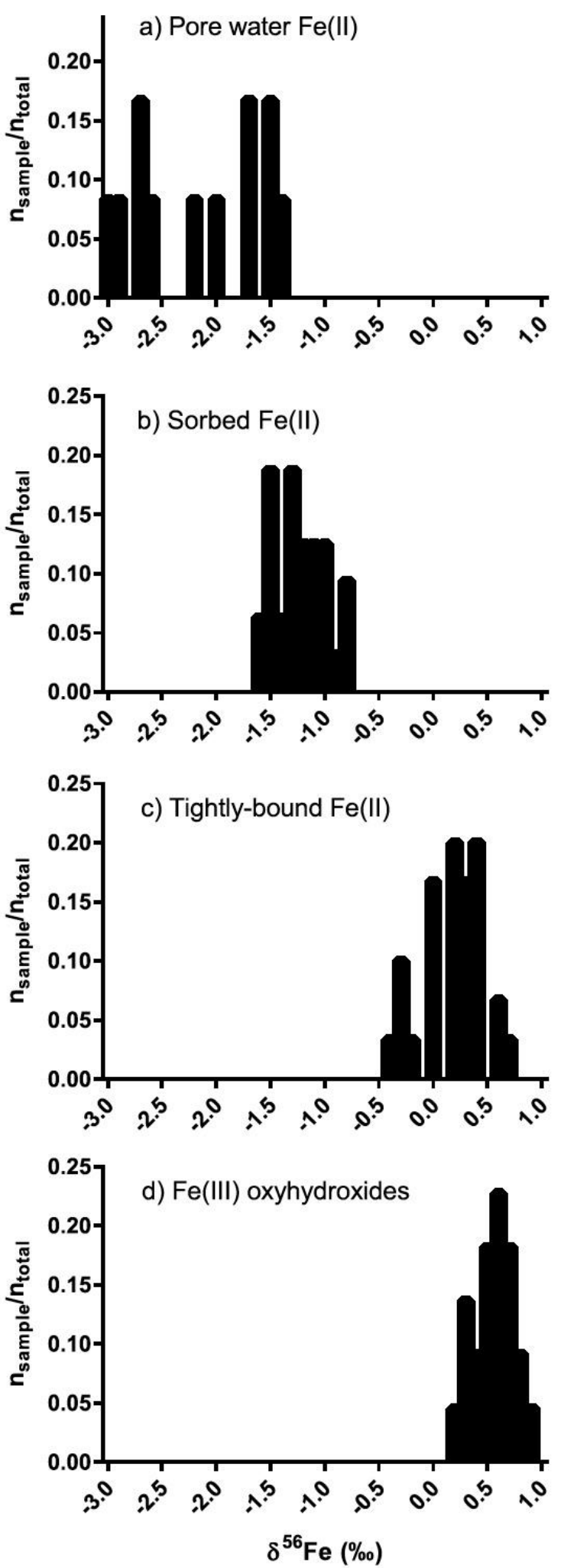

Fig. 4. Frequency diagram of calculated $\mathrm{Fe}$ isotope compositions for different Fe phases( pore water $\mathrm{Fe}(\mathrm{II})$, sorbed $\mathrm{Fe}(\mathrm{II})$, tightly-bound $\mathrm{Fe}(\mathrm{II})$ and $\mathrm{Fe}(\mathrm{III})$ oxyhydroxides) in Basin A and Basin $\mathrm{B}$. $n_{\text {sample }} / n_{\text {total }}$ represents number of samples out of total sample numbers in each category. $\delta^{56} \mathrm{Fe}$ is calculated based on measured $\mathrm{Fe}$ isotope compositions for pore water and acid extractions and the percentage of $\mathrm{Fe}(\mathrm{II})$ and $\mathrm{Fe}$ (III) concentrations in the pore water and extract 1 and 2. See text for details. 
Earlier studies have argued that sorption of $\mathrm{Fe}(\mathrm{II})$ to $\mathrm{Fe}(\mathrm{III})$ minerals may cause Fe isotope fractionation (Brantley et al., 2004; Bullen et al., 2001; Icopini et al., 2004). More recently, the fractionations associated with sorption of $\mathrm{Fe}(\mathrm{II})$ and with electron and atom exchange between aqueous $\mathrm{Fe}(\mathrm{II})$ and solid-phase $\mathrm{Fe}(\mathrm{III})$ have been measured (Crosby et al., 2007; Wu et al., 2009; Wu et al., 2010). These studies conclude that Fe(II) sorption induces much smaller fractionations (0.2$0.9 \%$ ) than DIR. The observed difference in $\delta^{56} \mathrm{Fe}$ between pore water $\mathrm{Fe}(\mathrm{II})$ and sorbed $\mathrm{Fe}(\mathrm{II})$ of $-0.9 \pm 0.4 \%$ in Basin $\mathrm{A}$ sediments falls within the range of fractionations expected for sorption of $\mathrm{Fe}(\mathrm{II})$ to $\mathrm{Fe}(\mathrm{III})$ oxyhydroxide minerals. (Note: if, as above, we account for possible oxidation artifacts by assuming that all pore water $\mathrm{Fe}$ was originally $\mathrm{Fe}(\mathrm{II})$, a lower limit of $-0.2 \pm 0.2 \%$ is obtained for the fractionation associated with Fe(II) sorption.)

\subsection{Comparison to other aquatic systems}

Isotopically light dissolved $\mathrm{Fe}(\mathrm{II})$, relative to $\mathrm{Fe}(\mathrm{III})$ oxyhydroxides, have been measured in the water columns of lakes exhibiting redox transitions (Table A.11). Negative $\delta^{56} \mathrm{Fe}$ values of dissolved $\mathrm{Fe}(\mathrm{II})$ at the $\mathrm{Fe}(\mathrm{III}) / \mathrm{Fe}(\mathrm{II})$ redox boundary in the water column of a seasonally anoxic lake were attributed by Malinovsky et al. (2005) to reflect partial oxidation of Fe(II). Busigny et al. (2014) similarly interpreted the $\mathrm{Fe}$ isotope shift across the $\mathrm{Fe}(\mathrm{III}) / \mathrm{Fe}(\mathrm{II})$ redox boundary in the water column of the anoxic and ferruginous Lake Pavin to record partial oxidation of Fe(II). Teutsch et al. (2009) showed an increasing trend of $\delta^{56} \mathrm{Fe}$ for dissolved $\mathrm{Fe}(\mathrm{II})$ from the epilimnion to the bottom of Lake Nyos, with the largest isotopic change found at the $\mathrm{Fe}(\mathrm{III}) / \mathrm{Fe}(\mathrm{II})$ redox transition. According to these authors, however, the isotopically lighter aqueous $\mathrm{Fe}(\mathrm{II})$ values are the result of DIR rather than $\mathrm{Fe}(\mathrm{II})$ oxidation. 
Few data exist on Fe Isotope compositions in lake sediments to which we can compare our results. Pore water and solid-phase $\delta^{56} \mathrm{Fe}$ values have been determined for Lake Pavin and Lake Geneva (Table A.11). Lake Pavin is a permanently stratified lake with an anoxic bottom water layer. The $\delta^{56} \mathrm{Fe}$ values of pore water, $\mathrm{HCl}$-extractable and bulk sediments in Lake Pavin are all close to one another and, on average, close to $0 \%$, which is the mean crustal $\delta^{56} \mathrm{Fe}$ value. In contrast, the $\delta^{56} \mathrm{Fe}$ values of pore water and sorbed $\mathrm{Fe}(\mathrm{II})$ are clearly negative in Basin A of Lake Tantaré, and distinct from the reactive $\mathrm{Fe}(\mathrm{III})$ sediment pool. A possible explanation is that, in Lake Pavin, complete Fe(III) reduction occurs above the SWI, as evidenced by the presence of $\mathrm{Fe}(\mathrm{III})$ oxyhydroxides in the water column but not in the sediments (Cosmidis et al., 2014). In other words, no Fe(III) reduction takes place below the SWI. In Basin A, however, the bottom waters are permanently oxygenated. As a consequence, $\mathrm{Fe}(\mathrm{III})$ reduction takes place within the sediments and pore water $\mathrm{Fe}(\mathrm{II})$ records the accompanying $\mathrm{Fe}$ isotope fractionation. The $\mathrm{HCl}$ extractions further suggest that some of the more resistant $\mathrm{Fe}(\mathrm{III})$ oxyhydroxides survive reduction and are buried with positive $\delta^{56} \mathrm{Fe}$ values in both Basin A and Basin B.

Lake Geneva is a unique environment where the bottom sediments studied are affected by outflow of a municipal sewage treatment plant. Extensive DIR occurs in the sediments due to input of organic carbon and elevated Fe concentrations from treated wastewater containing ferric chloride (Gibbs-Eggar et al., 1999). PercakDennett et al. (2013) found isotopically light Fe in pore water samples (Table A.11), similar to the values reported in this study. However, the solid-phase $\delta^{56} \mathrm{Fe}$ values for the Lake Geneva sediments are non-distinguishable between $\mathrm{HCl}$ leachable $\mathrm{Fe}$ oxides, Fe silicates, and bulk sediments, which is in contrast to the isotopically 
clearly separated Fe pools in Lake Tantaré sediments. The reason for this discrepancy is unclear.

We also compare our results to $\mathrm{Fe}$ isotope compositions of sediments from other aquatic systems (Table A.11). In general, larger ranges of $\delta^{56} \mathrm{Fe}$ values have been found for marine sediment pore waters $(-3.5$ to $1.1 \%$, $n=150$, Fehr et al., 2008; 2010; Homoky et al., 2009; 2013; Scholz et al., 2014a; 2014b; Severmann et al., 2006; 2008; 2010; Staubwasser et al., 2006) and brackish pore waters in estuaries ( -5.0 to $0.7 \%$, $n=48$, Rouxel et al., 2008; Roy et al., 2012). In comparison, pore waters in aquifers and mine drainage settings show a narrower range in $\delta^{56} \mathrm{Fe}$ values $(-2.4$ to $-0.2 \%, \mathrm{n}=22$, Guo et al., 2013; Herbert $\mathrm{Jr}$ and Schippers, 2008; Tangalos et al., 2010; Teutsch et al., 2005; Xie et al., 2013; 2014), which is similar to that for lake systems $(-2.1$ to $0.5 \%$, $n=52)$. The negative $\delta^{56} \mathrm{Fe}$ values of pore fluids in marine sediments have been attributed to the benthic efflux of isotopically light dissolved Fe produced by DIR in continental margins (Severmann et al., 2008). In estuaries, the isotopically light Fe of brackish pore waters have been interpreted to reflect a combination of processes including partial Fe(II) oxidation, DIR, and sorption (Rouxel et al., 2008; Roy et al., 2012). In aquifers, similar processes have also been used to explain the light $\mathrm{Fe}$ isotope enriched pore waters. In addition, microbial $\mathrm{Fe}(\mathrm{II})$ oxidation has been invoked to account for negative $\delta^{56} \mathrm{Fe}$ values for pore water from oxidized mine tailings (Herbert and Schippers, 2008).

Bulk sediments from marine settings $(-0.7$ to $0.4 \%, n=206)$ show a slightly smaller range in $\mathrm{Fe}$ isotope compositions than those from terrestrial aquatic environments $(-1.2$ to $0.7 \%, n=122)$, whereas the estuarine bulk sediments have the largest range $(-1.9$ to $1.5 \%, \mathrm{n}=55)$. Leaching with $0.5 \mathrm{M} \mathrm{HCl}$ yields a similar 
range to those of bulk sediments in all the settings (Table A.11). However, as shown in this study, a weaker $\mathrm{HCl}$ leach $(0.1 \mathrm{M} \mathrm{HCl})$, which removes mainly the sorbed $\mathrm{Fe}(\mathrm{II})$, could yield an Fe pool with a distinct isotope composition. 


\section{Concluding remarks}

This study presents the first comprehensive data set on the isotopic compositions of pore water and solid-bound Fe in sediments deposited in an oligotrophic freshwater lake. The Fe redox cycling within the upper centimeters of sediment produces distinctive signatures, with a clear separation of the $\delta^{56} \mathrm{Fe}$ values of the $\mathrm{Fe}(\mathrm{III})$ oxyhydroxides undergoing reduction and the resulting pore water $\mathrm{Fe}(\mathrm{II})$ and sorbed $\mathrm{Fe}(\mathrm{II})$. The apparent fractionation between pore water $\mathrm{Fe}(\mathrm{II})$ and the $\mathrm{Fe}(\mathrm{III})$ oxyhydroxides is $-2.6 \pm 0.5 \%$, that between pore water $\mathrm{Fe}(\mathrm{II})$ and sorbed $\mathrm{Fe}(\mathrm{II})$ is $-0.9 \pm 0.4 \%$. Potential oxidation artifacts would at most decrease these fractionations to $-1.4 \pm 0.4 \%$ and $-0.2 \pm 0.5 \%$, respectively. Overall, our field-based fractionations are consistent with those that have been observed in the laboratory with model iron-reducing bacteria and well-defined $\mathrm{Fe}(\mathrm{III})$ mineral phases. 


\section{References}

Beard, B.L., Johnson, C.M., 2004. Fe isotope variations in the modern and ancient earth and other planetary bodies, in: Johnson, C.M., Beard, B.L., Albaréde, F. (Eds.), Geochemistry of NonTraditional Stable Isotopes. Mineralogical Society of America, Washington, DC, pp. 319-357.

Beard, B.L., Johnson, C.M., Cox, L., Sun, H., Nealson, K.H., Aguilar, C., 1999. Iron isotope biosignatures. Science 285, 1889-1892.

Beard, B.L., Johnson, C.M., Skulan, J.L., Nealson, K.H., Cox, L., Sun, H., 2003. Application of Fe isotopes to tracing the geochemical and biological cycling of Fe. Chem. Geol 195, 87-117.

Beckler, J.S., Jones, M.E., Taillefert, M., 2015. The origin, composition, and reactivity of dissolved iron(III) complexes in coastal organic- and iron-rich sediments. Geochim. Cosmochim. Acta 152, 7288.

Belzile, N., Chen, Y.W., Xu, R., 2000. Early diagenetic behaviour of selenium in freshwater sediments. Appl. Geochem 15, 1439-1454.

Benner, S.G., Hansel, C.M., Wielinga, B.W., Barber, T.M., Fendorf, S., 2002. Reductive dissolution and biomineralization ofiron hydroxide under dynamic flow conditions. Environ. Sci. Technol 36, 1705-1711.

Bergquist, B.A., Boyle, E.A., 2006. Iron isotopes in the Amazon River system: Weathering and transport signatures. Earth Planet. Sci. Lett 248, 54-68.

Borrok, D.M., Wanty, R.B., Ian Ridley, W., Lamothe, P.J., Kimball, B.A., Verplanck, P.L., Runkel, R.L., 2009. Application of iron and zinc isotopes to track the sources and mechanisms of metal loading in a mountain watershed. Appl. Geochem. 24, 1270-1277.

Brantley, S.L., Liermann, L.J., Guynn, R.L., Anbar, A., Icopini, G.A., Barling, J., 2004. Fe isotopic fractionation during mineral dissolution with and without bacteria. Geochim. Cosmochim. Acta 68, 3189-3204.

Buerge, I.J., Hug, S.J., 1999. Influence of mineral surfaces on chromium(VI) reduction by iron(II). Environ. Sci. Technol 33, 4285-4291.

Bullen, T.D., White, A.F., Childs, C.W., Vivit, D.V., Schulz, M.S., 2001. Demonstration of significant abiotic iron isotope fractionation in nature. Geology 29, 699-702.

Busigny, V., Planavsky, N.J., Jézéquel, D., Crowe, S., Louvat, P., Moureau, J., Viollier, E., Lyons, T.W., 2014. Iron isotopes in an Archean ocean analogue. Geochim. Cosmochim. Acta 133, 443-462. Carignan, R., St-Pierre, S., Gachter, R., 1994. Use of diffusion samplers in oligotrophic lakesediment: effects of free oxygen in sampler material. Limnol. Oceanogr. 39, 468-474.

Catrouillet, C., Davranche, M., Dia, A., Bouhnik-Le Coz, M., Marsac, R., Pourret, O., Gruau, G., 2014. Geochemical modeling of Fe(II) binding to humic and fulvic acids. Chem. Geol 372, 109-118.

Chappaz, A., Gobeil, C., Tessier, A., 2008. Geochemical and anthropogenic enrichments of Mo in sediments from perennially oxic and seasonally anoxic lakes in Eastern Canada. Geochim. Cosmochim. Acta 72, 170-184.

Cosmidis J., B.K., Morin G., Busigny V., Lebeau O., Jézéquel D., Noël V., Dublet G. and Othmane G., 2014. Biomineralization of mixed valence iron-phosphates in the anoxic water column of Lake Pavin (Massif Central, France). Geochim Cosmochim Ac 126, 78-96.

Couture, R.-M., Gobeil, C., Tessier, A., 2008. Chronology of atmospheric deposition of arsenic inferred from reconstructed sedimentary records. Environ. Sci. Technol. 42, 6508-6513.

Couture, R.-M., Gobeil, C., Tessier, A., 2010a. Arsenic, iron and sulfur co-diagenesis in lake sediments. Geochim. Cosmochim. Acta 74, 1238-1255.

Couture, R.-M., Shafei, B., Van Cappellen, P., Tessier, A., Gobeil, C., 2010b. Non-steady state modeling of arsenic diagenesis in lake sediments. Environ. Sci. Technol. 44, 197-203.

Crosby, H.A., Johnson, C.M., Roden, E.E., Beard, B.L., 2005. Coupled Fe(II)-Fe(III) electron and atom exchange as a mechanism for $\mathrm{Fe}$ isotope fractionation during dissimilatory iron oxide reduction. Environ. Sci. Technol 39, 6698-6794.

Crosby, H.A., Roden, E.E., Johnson, C.M., Beard, B.L., 2007. The mechanisms of iron isotope fractionation produced during dissimilatory $\mathrm{Fe}(\mathrm{III})$ reduction by Shewanella putrefaciens and Geobacter sulfurreducens. Geobiology 5, 169-189.

Davis, C.C., Chen, H.-W., Edwards, M., 2002. Modeling silica sorption to iron hydroxide. Environ. Sci. Technol 36, 582-587.

Dideriksen, K., Baker, J.A., Stipp, S.L.S., 2008. Equilibrium Fe isotope fractionation between inorganic aqueous $\mathrm{Fe}(\mathrm{III})$ and the siderophore complex, $\mathrm{Fe}(\mathrm{III})$-desferrioxamine B. Earth Planet. Sci. Lett. 269, 280-290.

Domagal-Goldman, S.D., Kubicki, J.D., 2008. Density functional theory predictions of equilibrium isotope fractionation of iron due to redox changes and organic complexation. Geochim. 
Cosmochim. Acta 72, 5201-5216.

Domagal-Goldman, S.D., Paul, K.W., Sparks, D.L., Kubicki, J.D., 2009. Quantum chemical study of the $\mathrm{Fe}$ (III)-desferrioxamine B siderophore complex--Electronic structure, vibrational frequencies, and equilibrium Fe-isotope fractionation. Geochim. Cosmochim. Acta 73, 1-12.

Fehr, M.A., Andersson, P.S., Hålenius, U., Gustafsson, Ö., Mörth, C.-M., 2010. Iron enrichments and Fe isotopic compositions of surface sediments from the Gotland Deep, Baltic Sea. Chem. Geol. 277, 310-322.

Fehr, M.A., Andersson, P.S., Halenius, U., Morth, C.M., 2008. Iron isotope variations in Holocene sediments of the Gotland Deep, Baltic Sea. Geochim. Cosmochim. Acta 72, 807-826.

Feyte, S., Gobeil, C., Tessier, A., Cossa, D., 2012. Mercury dynamics in lake sediments. Geochim. Cosmochim. Acta 82, 92-112.

Feyte, S., Tessier, A., Gobeil, C., Cossa, D., 2010. In situ adsorption of mercury, methylmercury and other elements by iron oxyhydroxides and organic matter in lake sediments. Appl. Geochem. 25, 984-995.

Fortin, D., Leppard, G.G., Tessier, A., 1993. Characteristics of lacustrine diagenetic iron oxyhydroxides. Geochim. Cosmochim. Acta 57, 4391-4404.

Gibbs-Eggar, Z., Jude, B., Dominik, J., Loizeau, J.-L., Oldfield, F., 1999. Possible evidence for dissimilatory bacterial magnetite dominating the magnetic properties of recent lake sediments. Earth Planet. Sci. Lett. 168, 1-6.

Guo, H., Liu, C., Lu, H., Wanty, R.B., Wang, J., Zhou, Y., 2013. Pathways of coupled arsenic and iron cycling in high arsenic groundwater of the Hetao basin, Inner Mongolia, China: An iron isotope approach. Geochim. Cosmochim. Acta 112, 130-145.

Herbert Jr, R.B., Schippers, A., 2008. Iron isotope fractionation by biogeochemical processes in mine tailings. Environ. Sci. Technol. 42, 1117-1122.

Homoky, W.B., John, S.G., Conway, T.M., Mills, R.A., 2013. Distinct iron isotopic signatures and supply from marine sediment dissolution. Nat Commun 4.

Homoky, W.B., Severmann, S., Mills, R.A., Statham, P.J., Fones, G.R., 2009. Pore-fluid Fe isotopes reflect the extent of benthic Fe redox recycling: Evidence from continental shelf and deep-sea sediments. Geology 37, 751-754.

Hongve, D., 1997. Cycling of iron, manganese, and phosphate in a meromictic lake. Limnol. Oceanogr 42, 635-647.

Icopini, G.A., Anbar, A.D., Ruebush, S.S., Tien, M., Brantley, S.L., 2004. Iron isotope fractionation during microbial reduction of iron: the importance of adsorption. Geology 32, 205-208.

Johnson, C.M., Beard, B.L., Roden, E.E., 2008. The iron isotope fingerprints of redox and biogeochemical cycling in modern and ancient Earth. Annu. Rev. Earth. PI. Sc. 36, 457-493.

Johnson, C.M., Roden, E.E., Welch, S.A., Beard, B.L., 2005. Experimental constraints on Fe isotope fractionation during magnetite and Fe carbonate formation coupled to dissimilatory hydrous ferric oxide reduction. Geochim. Cosmochim. Acta 69, 963-993.

Lalonde, K., Mucci, A., Ouellet, A., Gelinas, Y., 2012. Preservation of organic matter in sediments promoted by iron. Nature 483, 198-200.

Liu, X.W., Millero, F.J., 2002. The solubility of iron in seawater. Mar. Chem 77, 43-54.

Malinovsky, D.N., Rodyushkin, I.V., Shcherbakova, E.P., Ponter, C., Ohlander, B., Ingri, J., 2005.

Fractionation of $\mathrm{Fe}$ isotopes as a result of redox processes in a basin. Geochem. Int. 43, 797-803.

Millero, F.J., 1998. Solubility of Fe(III) in seawater. Earth Planet. Sci. Lett 154, 323-329.

Millero, F.J., Sotolongo, S., Izaguirre, M., 1987. The oxidation kinetics of $\mathrm{Fe}(\mathrm{II})$ in seawater. Geochim. Cosmochim. Acta 51, 793-801.

Morgan, J.L.L., Wasylenki, L.E., Nuester, J., Anbar, A.D., 2011. Fe isotope fractionation during equilibration of Fe-organic complexes. Environ. Sci. Technol. 44, 6095-6101.

Payette, S., Filion, L., Delwaide, A., 1990. Distrubance regime of a cold temperate forest as deduced from tree-ring patterns: the Tantaré Ecological Reserve, Quebec. Can. J. For. Res. 20, 1228-1240.

Percak-Dennett, E.M., Beard, B.L., Xu, H., Konishi, H., Johnson, C.M., Roden, E.E., 2011. Iron isotope fractionation during microbial dissimilatory iron oxide reduction in simulated Archaean seawater. Geobiology 9, 205-220.

Percak-Dennett, E.M., Loizeau, J.-L., Beard, B.L., Johnson, C.M., Roden, E.E., 2013. Iron isotope geochemistry of biogenic magnetite-bearing sediments from the Bay of Vidy, Lake Geneva. Chem. Geol. 360-361, 32-40.

Pullin, M.J., Cabaniss, S.E., 2001. Colorimetric flow-injection analysis of dissolved iron in high DOC waters. Water Res. 35, 363-372.

Pullin, M.J., Cabaniss, S.E., 2003. The effects of $\mathrm{pH}$, ionic strength, and iron-fulvic acid interactions 
on the kinetics of non-photochemical iron transformations. I. Iron(II) oxidation and iron(III) colloid formation. Geochim. Cosmochim. Acta 67, 4067-4077.

Rouxel, O., Sholkovitz, E., Charette, M., Edwards, K.J., 2008. Iron isotope fractionation in subterranean estuaries. Geochim. Cosmochim. Acta 72, 3413-3430.

Roy, M., Rouxel, O., Martin, J.B., Cable, J.E., 2012. Iron isotope fractionation in a sulfide-bearing subterranean estuary and its potential influence on oceanic Fe isotope flux. Chem. Geol. 300, 133142.

Scholz, F., Severmann, S., McManus, J., Hensen, C., 2014a. Beyond the Black Sea paradigm: The sedimentary fingerprint of an open-marine iron shuttle. Geochim. Cosmochim. Acta 127, 368-380.

Scholz, F., Severmann, S., McManus, J., Noffke, A., Lomnitz, U., Hensen, C., 2014b. On the isotope composition of reactive iron in marine sediments: Redox shuttle versus early diagenesis. Chem. Geol. 389, 48-59.

Severmann, S., Johnson, C.M., Beard, B.L., McManus, J., 2006. The effect of early diagenesis on the $\mathrm{Fe}$ isotope compositions of porewaters and authigenic minerals in continental margin sediments. Geochim. Cosmochim. Acta 70, 2006-2022.

Severmann, S., Lyons, T.w., Anbar, A., McManus, J., Gordon, G., 2008. Modern iron isotope perspective on the benthic iron shuttle and the redox evolution of ancient oceans. Geology 36, 487490.

Severmann, S., McManus, J., Berelson, W.M., Hammond, D.E., 2010. The continental shelf benthic iron flux and its isotope composition. Geochim. Cosmochim. Acta 74, 3984-4004.

Skulan, J.L., Beard, B.L., Johnson, C.M., 2002. Kinetic and equilibrium Fe isotope fractionation between aqueous Fe(III) and hematite. Geochim. Cosmochim. Acta 66, 2995-3015.

Staubwasser, M., von Blanckenburg, F., Schoenberg, R., 2006. Iron isotopes in the early marine diagenetic iron cycle. Geology 34, 629-632.

Stookey, L.L., 1970. Ferrozine- a new spectrophotometric reagent for iron. Anal. Chem 42, 779-781.

Straub, K.L., Benz, M., Schink, B., Widdel, F., 1996. Anaerobic, nitrate-dependent microbial oxidation of ferrous iron. Appl. Environ. Microbiol 62, 1458-1460.

Tangalos, G.E., Beard, B.L., Johnson, C.M., Alpers, C.N., Shelobolina, E.S., Xu, H., Konishi, H., Roden, E.E., 2010. Microbial production of isotopically light iron(II) in a modern chemically precipitated sediment and implications for isotopic variations in ancient rocks. Geobiology 8, 197208.

Teutsch, N., Schmid, M., Muller, B., Halliday, A.N., Burgmann, H., Wehrli, B., 2009. Large iron isotope fractionation at the oxic-anoxic boundary in Lake Nyos. Earth Planet. Sci. Lett. 285, 52-60.

Teutsch, N., von Gunten, U., Porcelli, D., Cirpka, O.A., Halliday, A.N., 2005. Adsorption as a cause for iron isotope fractionation in reduced groundwater. Geochim. Cosmochim. Acta 69, 4175-4185.

Thamdrup, B., Fossing, H., Jørgensen, B.B., 1994. Manganese, iron, and sulfur cycling in a coastal marine sediment, Aarhus Bay, Denmark. Geochim. Cosmochim. Acta 58, 5115-5129.

Viollier, E., Inglett, P.W., Hunter, K., Roychoudhury, A.N., Van Cappellen, P., 2000. The ferrozine method revisited: $\mathrm{Fe}(\mathrm{II}) / \mathrm{Fe}(\mathrm{III})$ determination in natural waters. Appl. Geochem. 15, 785-790.

Wiederhold, J.G., Kraemer, S.M., Teutsch, N., Borer, P.M., Halliday, A.N., Kretzschmar, R., 2006. Iron isotope fractionation during proton-promoted, ligand-controlled, and reductive dissolution of goethite. Environ. Sci. Technol 40, 3787-3793.

Wiederhold, J.G., Teutsch, N., Kraemer, S.M., Halliday, A.N., Kretzschmar, R., 2007. Iron isotope fractionation in oxic soils by mineral weathering and podzolization. Geochim. Cosmochim. Acta 71, 5821-5833.

$\mathrm{Wu}$, L., Beard, B.L., Roden, E.E., Johnson, C.M., 2009. Influence of pH and dissolved Si on Fe isotope fractionation during dissimilatory microbial reduction of hematite. Geochim. Cosmochim. Acta 73, 5584-5599.

Wu, L., Beard, B.L., Roden, E.E., Kennedy, C.B., Johnson, C.M., 2010. Stable Fe isotope fractionations produced by aqueous Fe(II)-hematite surface interactions. Geochim. Cosmochim. Acta 74, 4249-4265.

Wu, L., Brucker, R.P., Beard, B.L., Roden, E.E., Johnson, C.M., 2013. Iron isotope characteristics of hot springs at Chocolate Pots, Yellowstone National Park. Astrobiology 13, 1091-1101.

Wu, L., Percak-Dennett, E.M., Beard, B.L., Roden, E.E., Johnson, C.M., 2012. Stable iron isotope fractionation between aqueous $\mathrm{Fe}(\mathrm{II})$ and model Archean ocean $\mathrm{Fe}-\mathrm{Si}$ coprecipitates and implications for iron isotope variations in the ancient rock record. Geochim. Cosmochim. Acta 84, 14-28.

Xie, X., Johnson, T.M., Wang, Y., Lundstrom, C.C., Ellis, A., Wang, X., Duan, M., 2013. Mobilization of arsenic in aquifers from the Datong Basin, China: Evidence from geochemical and iron isotopic data. Chemosphere 90, 1878-1884. 
Xie, X., Johnson, T.M., Wang, Y., Lundstrom, C.C., Ellis, A., Wang, X., Duan, M., Li, J., 2014. Pathways of arsenic from sediments to groundwater in the hyporheic zone: Evidence from an iron isotope study. J. Hydrol. 511, 509-517. 


\section{Appendices}

Table A. 1. Iron concentration for pore water samples from Basin A, Tantaré.

\begin{tabular}{|c|c|c|c|c|c|c|c|c|c|c|c|c|}
\hline \multirow{2}{*}{$\begin{array}{l}\text { Depth } \\
(\mathrm{cm})\end{array}$} & \multicolumn{4}{|c|}{ Peeper 1} & \multicolumn{4}{|c|}{ Peeper 2} & \multicolumn{4}{|c|}{ Peeper 3} \\
\hline & $\mathrm{Fe}(\mathrm{II}) \mu \mathrm{M}$ & $1 S D^{a}$ & $\mathrm{Fe}(\mathrm{III}) \mu \mathrm{M}$ & $1 S D$ & $\mathrm{Fe}(\mathrm{II}) \mu \mathrm{M}$ & $1 S D$ & $\mathrm{Fe}(\mathrm{III}) \mu \mathrm{M}$ & $1 S D$ & $\mathrm{Fe}(\mathrm{II}) \mu \mathrm{M}$ & $1 S D$ & $\mathrm{Fe}(\mathrm{III}) \mu \mathrm{M}$ & 1SD \\
\hline $\begin{array}{l}-4.5 \\
\end{array}$ & b.d. ${ }^{\mathrm{b}}$ & b.d. & 3.4 & 1.0 & 1.1 & 1.9 & 5.9 & 6.5 & b.d. & b.d. & 2.2 & 3.1 \\
\hline-3.5 & 2.0 & 2.0 & 3.4 & 3.9 & 0.7 & 1.3 & 7.8 & 6.8 & b.d. & b.d. & 1.8 & 3.2 \\
\hline-2.5 & 0.7 & 1.3 & 6.6 & 3.5 & b.d. & b.d. & 3.8 & 5.8 & 1.4 & 2.0 & 0.5 & 0.9 \\
\hline-1.5 & 1.4 & 2.5 & 4.1 & 0.3 & 0.7 & 1.3 & 3.9 & 4.7 & 0.9 & 1.2 & 3.4 & 3.2 \\
\hline-0.5 & 2.5 & 4.3 & 7.0 & 9.9 & b.d. & b.d. & 5.8 & 3.0 & 1.4 & 2.0 & 0.9 & 1.6 \\
\hline 0.5 & 5.2 & 4.8 & 11.5 & 14.9 & 12.1 & 2.7 & 12.7 & 2.5 & 3.1 & 3.2 & 5.4 & 9.3 \\
\hline 1.5 & 10.1 & 4.1 & 19.6 & 9.3 & 20.7 & 3.3 & 7.3 & 3.8 & 2.0 & 2.0 & 2.6 & 2.2 \\
\hline 2.5 & 7.5 & 4.6 & 14.7 & 12.5 & 19.7 & 0.4 & 9.2 & 2.9 & 9.7 & 3.6 & 15.2 & 8.1 \\
\hline 3.5 & 2.0 & 1.3 & 17.6 & 13.0 & 20.1 & 0.9 & 5.1 & 2.9 & 9.3 & 4.6 & 6.8 & 5.3 \\
\hline 4.5 & 3.5 & 2.9 & 12.8 & 2.5 & 20.1 & 0.6 & 5.6 & 5.1 & 10.1 & 2.9 & 9.7 & 7.9 \\
\hline 5.5 & 5.7 & 2.9 & 12.5 & 5.1 & 18.6 & 1.4 & 11.5 & 6.4 & 12.5 & 1.2 & 6.5 & 1.8 \\
\hline 6.5 & 4.2 & 2.4 & 6.7 & 3.7 & 19.4 & 1.3 & 5.9 & 5.2 & 9.5 & 1.2 & 7.9 & 3.5 \\
\hline 7.5 & 3.5 & 2.5 & 7.6 & 3.4 & 20.2 & 2.0 & 5.6 & 1.8 & 8.0 & 0.7 & 13.1 & 6.8 \\
\hline 8.5 & 0.5 & 0.4 & 5.7 & 0.2 & 19.8 & 1.9 & 6.5 & 3.2 & 9.5 & 1.1 & 8.6 & 6.1 \\
\hline 9.5 & b.d. & b.d. & 6.7 & 9.6 & 18.3 & 2.1 & 3.8 & 1.7 & 8.1 & 6.0 & 6.2 & 5.8 \\
\hline
\end{tabular}

a 1 SD is calculated based on analysis of three separate aliquots by ferrozine method.

${ }^{\mathrm{b}}$ b.d. denotes below detection limit, which is $0.5 \mu \mathrm{M}$. 
Table A. 2. Iron concentration for sediments in Basin A, Tantaré.

\begin{tabular}{|c|c|c|c|c|c|c|c|c|c|c|c|c|c|c|c|c|c|}
\hline \multirow{2}{*}{$\begin{array}{l}\text { Depth } \\
(\mathrm{cm})\end{array}$} & \multicolumn{5}{|c|}{ Extract 1} & \multicolumn{3}{|c|}{ Extract 2} & \multicolumn{2}{|c|}{ Extract 3} & \multirow{2}{*}{$\begin{array}{l}\mathrm{Fe}(\mathrm{II})_{\text {sum }} \\
\left(\mu \mathrm{mol} \mathrm{g}{ }^{-1}\right)\end{array}$} & \multirow[b]{2}{*}{ 1SD } & \multirow{2}{*}{$\begin{array}{l}\mathrm{Fe}(\mathrm{III})_{\text {sum }} \\
\left(\mu \mathrm{mol} \mathrm{g}{ }^{-1}\right)\end{array}$} & \multirow{2}{*}{$1 S D$} & \multirow{2}{*}{$\begin{array}{l}\mathrm{Fe}(\mathrm{tot})_{\text {sum }} \\
\left(\mu \mathrm{mol} \mathrm{g}{ }^{-1}\right)\end{array}$} & \multirow[b]{2}{*}{$1 S D$} & \multirow{2}{*}{$\begin{array}{l}\mathrm{Fe}(\mathrm{II})_{\text {sum }} \\
\mathrm{Fe}(\mathrm{tot})_{\text {sum }}\end{array}$} \\
\hline & $\begin{array}{l}\mathrm{Fe}(\mathrm{II}) \\
\left(\mu \mathrm{mol} \mathrm{g}{ }^{-1}\right)\end{array}$ & 1SD & $\begin{array}{l}\mathrm{Fe}(\mathrm{III}) \\
\left.(\mu \mathrm{mol} \mathrm{g})^{-1}\right)\end{array}$ & $1 S D$ & $\begin{array}{c}\mathrm{Fe}(\mathrm{II}) \\
\left(\mu \mathrm{mol} \mathrm{g}{ }^{-1}\right)\end{array}$ & $1 S D$ & $\begin{array}{l}\mathrm{Fe}(\mathrm{III}) \\
\left.(\mu \mathrm{mol} \mathrm{g})^{-1}\right)\end{array}$ & $1 S D$ & $\begin{array}{l}\text { Fetot } \\
\left(\mu \mathrm{mol} \mathrm{g}{ }^{-1}\right)\end{array}$ & $1 S D$ & & & & & & & \\
\hline $1 \sim 1.5$ & 36.3 & 1.9 & 8.7 & 0.5 & 81.4 & 1.7 & 193.4 & 8.4 & 162.7 & 4.4 & 117.8 & 2.6 & 202.1 & 8.4 & 482.6 & 11.1 & 0.24 \\
\hline $1.5 \sim 2$ & 31.9 & 2.7 & 13.4 & 5.5 & 72.8 & 0.7 & 131.7 & 8.8 & 194.2 & 4.2 & 104.7 & 2.7 & 145.1 & 10.4 & 444.1 & 10.8 & 0.24 \\
\hline $2 \sim 2.5$ & 32.1 & 0.0 & 6.6 & 1.3 & 64.8 & 2.1 & 67.6 & 0.2 & 155.4 & 0.5 & 96.9 & 2.1 & 74.2 & 1.3 & 326.5 & 2.6 & 0.30 \\
\hline $2.5 \sim 3$ & 25.2 & 4.6 & 11.3 & 1.7 & 63.3 & 0.4 & 90.0 & 5.1 & 165.3 & 1.0 & 88.5 & 4.6 & 101.3 & 5.4 & 355.2 & 8.5 & 0.25 \\
\hline $3 \sim 3.5$ & 30.8 & 0.2 & 7.5 & 2.2 & 61.3 & 2.0 & 60.5 & 12.9 & 158.6 & 9.6 & 92.0 & 2.0 & 68.0 & 13.1 & 318.7 & 14.7 & 0.29 \\
\hline $3.5 \sim 4$ & 32.2 & 2.0 & 5.5 & 0.5 & 66.2 & 2.9 & 42.4 & 6.9 & 166.7 & 15.4 & 98.4 & 3.5 & 47.9 & 6.9 & 313.0 & 18.3 & 0.31 \\
\hline $5 \sim 5.5$ & 35.4 & 0.5 & 8.4 & 3.6 & 55.9 & 1.8 & 32.5 & 6.1 & 119.6 & 2.8 & 91.3 & 1.9 & 40.8 & 7.1 & 251.6 & 6.6 & 0.36 \\
\hline $5.5 \sim 6$ & 33.0 & 5.4 & 9.7 & 3.8 & 53.4 & 5.9 & 14.8 & 2.1 & 108.6 & 16.8 & 86.4 & 8.0 & 24.5 & 4.4 & 219.5 & 19.5 & 0.39 \\
\hline $6 \sim 6.5$ & 36.4 & 0.4 & 4.6 & 4.3 & 55.7 & 0.4 & 28.1 & 1.1 & 112.4 & 2.3 & 92.1 & 0.6 & 32.7 & 4.4 & 237.2 & 4.5 & 0.39 \\
\hline $6.5 \sim 7$ & 37.8 & 4.6 & 1.7 & 2.4 & 52.7 & 1.6 & 13.8 & 4.3 & 101.2 & 4.9 & 90.5 & 4.9 & 15.4 & 4.9 & 206.1 & 5.7 & 0.44 \\
\hline $7 \sim 7.5$ & 37.6 & 2.2 & 8.8 & 4.4 & 53.9 & 0.6 & 17.4 & 1.0 & 107.5 & 9.3 & 91.5 & 2.2 & 26.1 & 4.5 & 225.2 & 9.5 & 0.41 \\
\hline $7.5 \sim 8$ & 36.6 & 0.8 & 4.8 & 3.7 & 44.2 & 6.6 & 18.2 & 4.2 & 82.1 & 9.7 & 80.8 & 6.6 & 23.0 & 5.6 & 185.9 & 15.1 & 0.43 \\
\hline $9 \sim 9.5$ & 41.5 & 1.5 & 3.0 & 0.4 & 52.4 & 0.2 & 19.6 & 5.2 & 94.3 & 0.6 & 93.9 & 1.5 & 22.6 & 5.2 & 210.8 & 5.2 & 0.45 \\
\hline $9.5 \sim 10$ & 39.5 & 1.1 & 9.6 & 2.4 & 50.0 & 2.6 & 19.8 & 7.6 & 88.1 & 7.9 & 89.5 & 2.8 & 29.4 & 7.9 & 206.9 & 12.9 & 0.43 \\
\hline $13 \sim 14$ & 43.6 & 0.7 & 3.6 & 1.8 & 50.7 & 1.1 & 16.0 & 0.4 & 92.7 & 1.2 & 94.3 & 1.3 & 19.5 & 1.8 & 206.5 & 2.2 & 0.46 \\
\hline $17 \sim 18$ & 44.4 & 2.9 & 7.3 & 1.0 & 46.2 & 1.7 & 15.0 & 3.0 & 78.5 & 3.0 & 90.6 & 3.3 & 22.3 & 3.2 & 191.4 & 5.1 & 0.47 \\
\hline $20 \sim 21$ & 42.1 & 0.4 & 6.2 & 2.2 & 50.4 & 1.8 & 14.4 & 0.5 & 74.1 & 12.2 & 92.4 & 1.9 & 20.6 & 2.2 & 187.2 & 12.4 & 0.49 \\
\hline $24 \sim 25$ & 37.1 & 2.4 & 10.4 & 0.3 & 49.1 & 0.8 & 20.1 & 3.1 & 87.1 & 1.1 & 86.2 & 2.5 & 30.5 & 3.1 & 203.8 & 4.8 & 0.42 \\
\hline $26 \sim 27$ & 51.7 & 1.0 & 5.0 & 1.8 & 49.4 & 0.2 & 12.6 & 3.5 & 80.5 & 5.5 & 101.1 & 1.0 & 17.7 & 3.9 & 199.2 & 7.0 & 0.51 \\
\hline $29 \sim 30$ & 55.1 & 6.2 & 4.9 & 2.4 & 61.0 & 9.7 & 15.0 & 2.8 & 94.7 & 7.0 & 116.1 & 11.5 & 19.9 & 3.7 & 230.7 & 10.6 & 0.50 \\
\hline
\end{tabular}


Table A. 3. Iron concentration for sediments in Basin B, Tantaré.

\begin{tabular}{|c|c|c|c|c|c|c|c|c|c|c|c|c|c|c|c|c|c|}
\hline \multirow[b]{2}{*}{$\begin{array}{l}\text { Depth } \\
\text { (cm) }\end{array}$} & \multicolumn{4}{|c|}{ Extract 1} & \multicolumn{4}{|c|}{ Extract 2} & \multicolumn{2}{|c|}{ Extract 3} & \multirow[b]{2}{*}{$\underset{\left(\mu \mathrm{mol} \mathrm{g}{ }^{-1}\right)}{\mathrm{Fe}(\mathrm{II})_{\text {sum }}}$} & \multicolumn{3}{|c|}{$\mathrm{Fe}(\mathrm{III})_{\text {sum }}$} & \multirow{2}{*}{$\begin{array}{r}\mathrm{Fe}(\mathrm{tot})_{\text {sum }} \\
(\mu \mathrm{mol} \mathrm{g} \\
\mathrm{g}^{-} \\
1\end{array}$} & \multirow{2}{*}{\multicolumn{2}{|c|}{$\begin{array}{c}\mathrm{Fe}(\mathrm{II})_{\mathrm{sum}} \\
\mathrm{Fe}(\mathrm{tot})_{\text {sum }}\end{array}$}} \\
\hline & $\begin{array}{c}\mathrm{Fe}(\mathrm{II}) \\
\left.(\mu \mathrm{mol} \mathrm{g})^{-1}\right)\end{array}$ & 1SD & $\begin{array}{c}\mathrm{Fe}(\mathrm{III}) \\
\left.(\mu \mathrm{mol} \mathrm{g})^{-1}\right) \\
\end{array}$ & 1SD & $\begin{array}{c}\mathrm{Fe}(\mathrm{II}) \\
\left.(\mu \mathrm{mol} \mathrm{g})^{-1}\right) \\
\end{array}$ & $1 S D$ & $\begin{array}{c}\mathrm{Fe}(\mathrm{III}) \\
\left(\mu \mathrm{mol} \mathrm{g}{ }^{-1}\right) \\
\end{array}$ & $1 S D$ & $\begin{array}{c}\text { Fetot } \\
\left.(\mu \mathrm{mol} \mathrm{g})^{-1}\right)\end{array}$ & 1SD & & 1SD & $\left(\mu \mathrm{mol} \mathrm{g}^{-}\right.$ & $1 S D$ & & & \\
\hline "0 0.5 & 131.4 & 4.0 & 87.9 & 1.3 & 98.6 & 1.2 & 144.2 & 3.5 & 123.7 & 12.6 & 230.0 & 4.2 & 232.1 & 3.7 & 585.8 & 14.5 & 0.39 \\
\hline $1 \sim 1.5$ & 113.2 & 5.3 & 81.5 & 5.6 & 128.5 & 6.9 & 155.7 & 0.5 & 107.9 & 0.3 & 241.7 & 8.7 & 237.2 & 5.6 & 586.8 & 13.2 & 0.41 \\
\hline $1.5 \sim 2$ & 118.9 & 3.3 & 76.3 & 1.8 & 135.8 & 8.6 & 140.9 & 7.3 & 115.7 & 5.9 & 254.7 & 9.3 & 217.2 & 7.6 & 587.6 & 17.1 & 0.43 \\
\hline $2.5 \sim 3$ & 125.7 & 7.2 & 73.4 & 1.4 & 133.8 & 7.3 & 140.0 & 5.5 & 107.8 & 4.4 & 259.6 & 10.3 & 213.4 & 5.7 & 580.7 & 9.8 & 0.45 \\
\hline $3.5 \sim 4$ & 122.1 & 6.1 & 64.6 & 8.0 & 133.4 & 10.1 & 116.0 & 1.6 & 129.8 & 1.8 & 255.5 & 11.8 & 180.6 & 8.1 & 565.9 & 8.9 & 0.45 \\
\hline $4 \sim 4.5$ & 123.3 & 2.9 & 79.2 & 3.7 & 87.0 & 3.4 & 88.7 & 5.3 & 120.0 & 1.2 & 210.3 & 4.5 & 168.0 & 6.5 & 498.3 & 8.8 & 0.42 \\
\hline $4.5 \sim 5$ & 141.6 & 4.3 & 90.0 & 2.0 & 62.4 & 2.4 & 69.3 & 2.5 & 120.0 & 6.1 & 204.0 & 4.9 & 159.2 & 3.2 & 483.3 & 8.7 & 0.42 \\
\hline $6 \sim 6.5$ & 128.9 & 3.9 & 83.2 & 3.7 & 63.0 & 0.8 & 63.1 & 6.6 & 136.1 & 2.3 & 191.9 & 4.0 & 146.3 & 7.5 & 474.4 & 9.8 & 0.40 \\
\hline $6.5 \sim 7$ & 129.5 & 6.3 & 82.0 & 0.1 & 59.3 & 7.1 & 60.3 & 0.9 & 132.3 & 8.5 & 188.8 & 9.5 & 142.4 & 0.9 & 463.5 & 13.3 & 0.41 \\
\hline $7.5 \sim 8$ & 107.2 & 0.4 & 64.5 & 0.4 & 94.3 & 1.9 & 77.0 & 2.3 & 164.8 & 4.5 & 201.5 & 2.0 & 141.5 & 2.3 & 507.8 & 6.2 & 0.40 \\
\hline $9 \sim 9.5$ & 119.2 & 6.2 & 60.2 & 6.0 & 91.1 & 4.4 & 72.6 & 2.2 & 168.7 & 5.0 & 210.3 & 7.6 & 132.8 & 6.4 & 511.8 & 8.3 & 0.41 \\
\hline $10 \sim 11$ & 123.0 & 1.7 & 70.8 & 1.4 & 70.6 & 2.7 & 64.2 & 1.8 & 146.5 & 6.8 & 193.7 & 3.2 & 135.0 & 2.3 & 475.2 & 6.9 & 0.41 \\
\hline $12 \sim 13$ & 90.7 & 7.2 & 46.8 & 0.2 & 91.2 & 3.4 & 67.3 & 2.8 & 136.4 & 10.3 & 181.9 & 8.0 & 114.1 & 2.8 & 432.4 & 12.4 & 0.42 \\
\hline $15 \sim 16$ & 105.1 & 4.8 & 73.7 & 4.5 & 58.3 & 3.3 & 53.3 & 0.9 & 131.5 & 3.7 & 163.4 & 5.8 & 127.0 & 4.6 & 421.9 & 4.4 & 0.39 \\
\hline $17 \sim 18$ & 99.0 & 9.7 & 74.9 & 1.5 & 91.8 & 1.7 & 66.5 & 2.4 & 129.3 & 1.2 & 190.8 & 9.8 & 141.4 & 2.8 & 461.4 & 8.4 & 0.41 \\
\hline 20 21 & 88.9 & 8.0 & 46.4 & 6.7 & 83.3 & 1.7 & 74.9 & 7.1 & 118.7 & 3.4 & 172.3 & 8.2 & 121.3 & 9.8 & 412.3 & 9.5 & 0.42 \\
\hline 22 23 & 116.3 & 10.4 & 67.5 & 15.0 & 64.0 & 4.6 & 40.5 & 3.2 & 129.4 & 12.5 & 180.3 & 11.3 & 108.0 & 15.3 & 417.7 & 13.4 & 0.43 \\
\hline 24 25 & 104.9 & 4.1 & 45.0 & 5.2 & 120.8 & 3.6 & 97.2 & 5.5 & 147.3 & 7.8 & 225.7 & 5.4 & 142.3 & 7.6 & 515.3 & 8.1 & 0.44 \\
\hline 26 27 & 82.7 & 2.7 & 64.0 & 7.8 & 95.6 & 6.1 & 67.8 & 3.2 & 137.4 & 6.9 & 178.4 & 6.7 & 131.9 & 8.5 & 447.6 & 9.1 & 0.40 \\
\hline 28 29 & 122.1 & 8.7 & 78.1 & 3.9 & 60.7 & 0.1 & 51.1 & 2.2 & 139.3 & 7.0 & 182.8 & 8.7 & 129.2 & 4.5 & 451.4 & 8.7 & 0.41 \\
\hline
\end{tabular}


Table A. 4. $\delta^{56} \mathrm{Fe}$ values for pore water samples from Basin A, Tantaré.

\begin{tabular}{|c|c|c|c|c|}
\hline \multirow[b]{2}{*}{ Depth(cm) } & \multicolumn{2}{|c|}{ Peeper 2} & \multicolumn{2}{|c|}{ Peeper 3} \\
\hline & $\begin{array}{c}\delta^{56} \mathrm{Fe} \\
(\%) \\
\end{array}$ & $1 S D$ & $\begin{array}{c}\delta^{56} \mathrm{Fe} \\
(\%) \\
\end{array}$ & $1 S D$ \\
\hline 0.5 & -1.05 & 0.01 & NA & NA \\
\hline 1.5 & NA & NA & -0.87 & 0.05 \\
\hline 2.5 & -0.85 & 0.00 & NA & NA \\
\hline 4.5 & -1.10 & 0.10 & -1.96 & 0.08 \\
\hline 5.5 & -1.09 & 0.03 & -1.43 & 0.01 \\
\hline 6.5 & -1.13 & 0.04 & -2.10 & 0.01 \\
\hline 8.5 & -1.30 & 0.00 & -1.83 & 0.13 \\
\hline 9.5 & -1.25 & 0.03 & NA & NA \\
\hline
\end{tabular}

Table A. 5. $\delta^{56} \mathrm{Fe}$ values for sediments in Basin A, Tantaré.

\begin{tabular}{|c|c|c|c|c|c|c|}
\hline \multirow[b]{2}{*}{ Depth $(\mathrm{cm})$} & \multicolumn{2}{|c|}{ Extract 1} & \multicolumn{2}{|c|}{ Extract 2} & \multicolumn{2}{|c|}{ Extract 3} \\
\hline & $\begin{array}{c}\delta^{56} \mathrm{Fe} \\
(\% \circ)\end{array}$ & $1 S D$ & $\begin{array}{c}\delta^{56} \mathrm{Fe} \\
(\% \circ)\end{array}$ & $1 S D$ & $\begin{array}{c}\delta^{56} \mathrm{Fe} \\
(\%)\end{array}$ & $1 S D$ \\
\hline $1 \sim 1.5$ & -0.53 & 0.08 & 0.45 & 0.02 & 0.76 & 0.04 \\
\hline $1.5 \sim 2$ & -0.68 & 0.12 & NA & NA & 0.35 & 0.02 \\
\hline $2 \sim 2.5$ & -0.84 & 0.02 & 0.51 & 0.01 & 0.26 & 0.01 \\
\hline $2.5 \sim 3$ & -0.53 & 0.14 & NA & NA & 0.36 & 0.01 \\
\hline $3 \sim 3.5$ & -0.86 & 0.08 & 0.43 & 0.08 & 0.44 & 0.02 \\
\hline 3.5 4 & -0.96 & 0.02 & 0.55 & 0.06 & 0.34 & 0.02 \\
\hline $5 \sim 5.5$ & -0.82 & 0.01 & 0.42 & 0.04 & 0.55 & 0.02 \\
\hline $5.5 \sim 6$ & -0.95 & 0.09 & 0.39 & 0.12 & 0.47 & 0.01 \\
\hline $6 \sim 6.5$ & -0.91 & 0.06 & 0.36 & 0.01 & 0.54 & 0.02 \\
\hline $6.5 \sim 7$ & -1.06 & 0.04 & 0.44 & 0.01 & 0.50 & 0.02 \\
\hline $7 \sim 7.5$ & -1.00 & 0.05 & 0.34 & 0.01 & 0.51 & 0.02 \\
\hline 7.5 8 & -0.90 & 0.04 & 0.35 & 0.07 & 0.62 & 0.02 \\
\hline $9 \sim 9.5$ & -0.99 & 0.10 & 0.43 & 0.02 & 0.85 & 0.03 \\
\hline $9.5 \sim 10$ & -1.01 & 0.08 & 0.48 & 0.03 & 0.69 & 0.02 \\
\hline $13 \sim 14$ & -0.99 & 0.06 & 0.43 & 0.01 & 0.67 & 0.02 \\
\hline $17 \sim 18$ & -1.17 & 0.08 & 0.55 & 0.03 & 0.70 & 0.02 \\
\hline 20 21 & -1.21 & 0.01 & 0.48 & 0.02 & NA & NA \\
\hline 24 25 & -0.89 & 0.05 & 0.23 & 0.02 & 0.65 & 0.02 \\
\hline 26 27 & -0.97 & 0.08 & 0.43 & 0.02 & 0.72 & 0.02 \\
\hline $29 \sim 30$ & -1.18 & 0.03 & 0.38 & 0.01 & 0.75 & 0.02 \\
\hline
\end{tabular}


Table A. $6 \delta^{56} \mathrm{Fe}$ values for sediments in Basin B, Tantaré.

\begin{tabular}{|c|c|c|c|c|c|c|}
\hline \multirow[b]{2}{*}{ Depth $(\mathrm{cm})$} & \multicolumn{2}{|c|}{ Extract 1} & \multicolumn{2}{|c|}{ Extract 2} & \multicolumn{2}{|c|}{ Extract 3} \\
\hline & $\begin{array}{l}\delta^{56} \mathrm{Fe} \\
(\%) \\
(\%)\end{array}$ & $1 S D$ & $\begin{array}{l}\delta^{56} \mathrm{Fe} \\
(\%)\end{array}$ & $1 S D$ & $\begin{array}{c}\delta^{56} \mathrm{Fe} \\
(\% \circ)\end{array}$ & $1 \mathrm{SD}$ \\
\hline $0 \sim 0.5$ & -0.28 & 0.08 & 0.37 & 0.06 & 0.89 & 0.02 \\
\hline $0.5 \sim 1$ & -0.23 & 0.04 & 0.42 & 0.02 & NA & NA \\
\hline $1 \sim 1.5$ & -0.53 & 0.06 & 0.46 & 0.03 & NA & NA \\
\hline $1.5 \sim 2$ & -0.55 & 0.03 & 0.44 & 0.06 & NA & NA \\
\hline $3.5 \sim 4$ & -0.57 & 0.08 & 0.45 & 0.10 & NA & NA \\
\hline $4.5 \sim 5$ & -0.19 & 0.01 & 0.59 & 0.07 & NA & NA \\
\hline $6.5 \sim 7$ & -0.20 & 0.03 & 0.37 & 0.12 & NA & NA \\
\hline 9 9.5 & -0.57 & 0.02 & 0.51 & 0.05 & 0.62 & 0.01 \\
\hline $10 \sim 11$ & -0.25 & 0.01 & 0.68 & 0.11 & NA & NA \\
\hline $15 \sim 16$ & -0.24 & 0.08 & 0.40 & 0.00 & NA & NA \\
\hline 22 23 & -0.22 & 0.08 & 0.23 & 0.00 & NA & NA \\
\hline 28 29 & -0.24 & 0.01 & 0.28 & 0.00 & 0.94 & 0.02 \\
\hline
\end{tabular}

Table A. 7. $\delta^{56} \mathrm{Fe}$ values for sediments in Basin A, Tantaré.

\begin{tabular}{|c|c|c|c|c|c|c|c|c|c|c|}
\hline \multirow[b]{2}{*}{ Depth(cm) } & \multicolumn{2}{|c|}{ Peeper 2} & \multicolumn{2}{|c|}{ Peeper 3} & \multirow[b]{2}{*}{$\begin{array}{l}\text { Sorbed } \\
\mathrm{Fe}(\mathrm{II}) \\
(\%)\end{array}$} & \multirow[b]{2}{*}{$1 S D$} & \multirow[b]{2}{*}{$\begin{array}{c}\text { Tightly-bound } \\
\text { Fe(II) } \\
(\%)\end{array}$} & \multirow[b]{2}{*}{$1 S D$} & \multirow[b]{2}{*}{$\begin{array}{c}\mathrm{Fe}(\mathrm{III}) \\
\text { oxyhydroxides } \\
(\%)\end{array}$} & \multirow[b]{2}{*}{$1 S D$} \\
\hline & $\begin{array}{c}\text { Aqueous } \\
\text { Fe(II) } \\
(\% \circ)\end{array}$ & & $\begin{array}{l}\text { Aqueous } \\
\mathrm{Fe}(\mathrm{II}) \\
(\% 0)\end{array}$ & $1 S D$ & & & & & & \\
\hline $1 \sim 1.5$ & -2.95 & 0.72 & -1.44 & 3.74 & -0.82 & 0.12 & -0.30 & 0.15 & 0.76 & 0.04 \\
\hline $1.5 \sim 2$ & NA & NA & NA & NA & -1.28 & 0.21 & NA & 0.06 & 0.35 & 0.02 \\
\hline 2 2.5 & -1.37 & 0.14 & NA & NA & -1.03 & 0.04 & 0.77 & 0.04 & 0.26 & 0.01 \\
\hline $2.5 \sim 3$ & NA & NA & NA & NA & -0.93 & 0.32 & NA & 0.04 & 0.36 & 0.01 \\
\hline $3 \sim 3.5$ & NA & NA & NA & NA & -1.24 & 0.12 & 0.42 & 0.20 & 0.44 & 0.02 \\
\hline $3.5 \sim 4$ & -1.50 & 0.32 & -2.59 & 1.57 & -1.20 & 0.09 & 0.67 & 0.14 & 0.34 & 0.02 \\
\hline $5 \sim 5.5$ & -2.11 & 0.47 & -2.66 & 0.44 & -1.24 & 0.12 & 0.33 & 0.09 & 0.55 & 0.02 \\
\hline $5.5 \sim 6$ & NA & NA & NA & NA & -1.43 & 0.40 & 0.37 & 0.17 & 0.47 & 0.01 \\
\hline $6 \sim 6.5$ & -1.64 & 0.36 & -2.90 & 1.15 & -1.22 & 0.13 & 0.27 & 0.02 & 0.54 & 0.02 \\
\hline $6.5 \sim 7$ & NA & NA & NA & NA & -1.21 & 0.15 & 0.43 & 0.04 & 0.50 & 0.02 \\
\hline 7 7.5 & NA & NA & NA & NA & -1.49 & 0.12 & 0.28 & 0.02 & 0.51 & 0.02 \\
\hline $7.5 \sim 8$ & -1.93 & 0.34 & -2.64 & 1.21 & -1.20 & 0.14 & 0.24 & 0.22 & 0.62 & 0.02 \\
\hline $9 \sim 9.5$ & -1.69 & 0.23 & NA & NA & -1.14 & 0.12 & 0.24 & 0.10 & 0.85 & 0.03 \\
\hline $9.5 \sim 10$ & NA & NA & NA & NA & -1.50 & 0.11 & 0.37 & 0.18 & 0.69 & 0.02 \\
\hline $13 \sim 14$ & NA & NA & NA & NA & -1.08 & 0.08 & 0.35 & 0.04 & 0.67 & 0.02 \\
\hline $17 \sim 18$ & NA & NA & NA & NA & -1.47 & 0.18 & 0.49 & 0.05 & 0.70 & 0.02 \\
\hline 20 21 & NA & NA & NA & NA & -1.57 & 0.05 & 0.43 & 0.03 & NA & NA \\
\hline 24 25 & NA & NA & NA & NA & -1.31 & 0.14 & 0.08 & 0.06 & 0.65 & 0.02 \\
\hline 26 27 & NA & NA & NA & NA & -1.18 & 0.12 & 0.34 & 0.06 & 0.72 & 0.02 \\
\hline 29 30 & NA & NA & NA & NA & -1.44 & 0.20 & 0.26 & 0.16 & 0.75 & 0.02 \\
\hline
\end{tabular}


Table A. 8. $\delta^{56} \mathrm{Fe}$ values for different iron phases and iron isotope mass balance in Basin B, Tantaré.

\begin{tabular}{ccccccr}
\hline \hline Depth(cm) & $\begin{array}{c}\text { Sorbed } \\
\text { Fe(II) } \\
(\%)\end{array}$ & $1 S D$ & $\begin{array}{c}\text { Tightly-bound } \\
\text { Fe(II) } \\
(\% \circ)\end{array}$ & $\begin{array}{c}\text { Fe(III) } \\
(\%)\end{array}$ & $\begin{array}{c}\text { oxyhydroxides } \\
(\%)\end{array}$ & $1 S D$ \\
\hline \hline $0 \sim 0.5$ & -1.07 & 0.14 & -0.40 & 0.16 & 0.89 & 0.02 \\
$0.5 \sim 1$ & -1.04 & 0.07 & -0.22 & 0.09 & NA & NA \\
$1 \sim 1.5$ & -1.51 & 0.16 & 0.05 & 0.10 & NA & NA \\
$1.5 \sim 2$ & -1.43 & 0.06 & 0.09 & 0.17 & NA & NA \\
$3.5 \sim 4$ & -1.35 & 0.14 & 0.22 & 0.20 & NA & NA \\
$4.5 \sim 5$ & -0.75 & 0.05 & 0.46 & 0.15 & NA & NA \\
$6.5 \sim 7$ & -0.72 & 0.08 & 0.09 & 0.28 & NA & NA \\
$9 \sim 9.5$ & -1.24 & 0.07 & 0.43 & 0.12 & 0.62 & 0.01 \\
$10 \sim 11$ & -0.78 & 0.02 & 0.66 & 0.21 & NA & NA \\
$15 \sim 16$ & -0.91 & 0.14 & 0.03 & 0.06 & NA & NA \\
$22 \sim 23$ & -0.99 & 0.17 & -0.12 & 0.07 & NA & NA \\
$28 \sim 29$ & -0.93 & 0.11 & -0.25 & 0.04 & 0.94 & 0.02 \\
\hline \hline
\end{tabular}


Table A. 9. Summary of iron isotope measurements and mass balance calculation for Basin A, Tantaré.

\begin{tabular}{|c|c|c|c|c|c|c|c|c|c|c|c|c|c|c|c|c|}
\hline \multirow[b]{2}{*}{$\begin{array}{l}\text { Depth } \\
(\mathrm{cm})\end{array}$} & \multicolumn{4}{|c|}{ Extract 1} & \multicolumn{4}{|c|}{ Extract 2} & \multicolumn{4}{|c|}{ Extract 3} & \multirow[b]{2}{*}{$\mathrm{Fe}(\text { tot })_{\text {sum }}$} & \multirow[b]{2}{*}{ 1SD } & \multirow[b]{2}{*}{$\delta^{56} \mathrm{Fe}_{\text {balance }}$} & \multirow[b]{2}{*}{$1 S D$} \\
\hline & $\begin{array}{c}\delta^{56} \mathrm{Fe} \\
\% \text { o }\end{array}$ & $1 S D$ & $\begin{array}{c}\text { Fetot } \\
(\mu \mathrm{mol} / \mathrm{g})\end{array}$ & $1 S D$ & $\begin{array}{c}\delta^{56} \mathrm{Fe} \\
\% \text { o }\end{array}$ & $1 S D$ & $\begin{array}{c}\text { Fetot } \\
(\mu \mathrm{mol} / \mathrm{g})\end{array}$ & $1 S D$ & $\begin{array}{c}\delta^{56} \mathrm{Fe} \\
\% \text { o }\end{array}$ & $1 S D$ & $\begin{array}{c}\text { Fetot } \\
(\mu \mathrm{mol} / \mathrm{g})\end{array}$ & $1 S D$ & & & & \\
\hline $1 \sim 1.5$ & -0.53 & 0.08 & 45.1 & 1.5 & 0.45 & 0.02 & 274.8 & 10.1 & 0.76 & 0.04 & 162.7 & 4.4 & 482.6 & 11.1 & 0.46 & 0.000 \\
\hline $1.5 \sim 2$ & -0.68 & 0.12 & 45.3 & 2.8 & 0.48 & 0.02 & 204.5 & 9.5 & 0.35 & 0.02 & 194.2 & 4.2 & 444.1 & 10.8 & 0.31 & 0.000 \\
\hline 2 2.5 & -0.84 & 0.02 & 38.7 & 1.3 & 0.51 & 0.01 & 132.4 & 2.3 & 0.26 & 0.01 & 155.4 & 0.5 & 326.5 & 2.6 & 0.23 & 0.000 \\
\hline $2.5 \sim 3$ & -0.53 & 0.14 & 36.6 & 6.3 & 0.47 & 0.01 & 153.2 & 5.5 & 0.36 & 0.01 & 165.3 & 1.0 & 355.2 & 8.5 & 0.32 & 0.000 \\
\hline $3 \sim 3.5$ & -0.86 & 0.08 & 38.3 & 2.0 & 0.43 & 0.08 & 121.8 & 10.9 & 0.44 & 0.02 & 158.6 & 9.6 & 318.7 & 14.7 & 0.28 & 0.001 \\
\hline $3.5 \sim 4$ & -0.96 & 0.02 & 37.7 & 1.5 & 0.55 & 0.06 & 108.6 & 9.8 & 0.34 & 0.02 & 166.7 & 15.4 & 313.0 & 18.3 & 0.25 & 0.001 \\
\hline $5 \sim 5.5$ & -0.82 & 0.01 & 43.8 & 4.1 & 0.42 & 0.04 & 88.3 & 4.3 & 0.55 & 0.02 & 119.6 & 2.8 & 251.6 & 6.6 & 0.27 & 0.000 \\
\hline $5.5 \sim 6$ & -0.95 & 0.09 & 42.7 & 9.2 & 0.39 & 0.12 & 68.2 & 3.8 & 0.47 & 0.01 & 108.6 & 16.8 & 219.5 & 19.5 & 0.17 & 0.002 \\
\hline $6 \sim 6.5$ & -0.91 & 0.06 & 41.0 & 3.8 & 0.36 & 0.01 & 83.8 & 0.7 & 0.54 & 0.02 & 112.4 & 2.3 & 237.2 & 4.5 & 0.23 & 0.000 \\
\hline $6.5 \sim 7$ & -1.06 & 0.04 & 38.4 & 0.8 & 0.44 & 0.01 & 66.5 & 2.8 & 0.50 & 0.02 & 101.2 & 4.9 & 206.1 & 5.7 & 0.19 & 0.000 \\
\hline $7 \sim 7.5$ & -1.00 & 0.05 & 46.4 & 2.2 & 0.34 & 0.01 & 71.3 & 0.4 & 0.51 & 0.02 & 107.5 & 9.3 & 225.2 & 9.5 & 0.14 & 0.000 \\
\hline 7.5 8 & -0.90 & 0.04 & 41.4 & 4.5 & 0.35 & 0.07 & 62.4 & 10.7 & 0.62 & 0.02 & 82.1 & 9.7 & 185.9 & 15.1 & 0.19 & 0.001 \\
\hline $9 \sim 9.5$ & -0.99 & 0.10 & 44.5 & 1.2 & 0.43 & 0.02 & 72.0 & 5.0 & 0.85 & 0.03 & 94.3 & 0.6 & 210.8 & 5.2 & 0.32 & 0.000 \\
\hline $9.5 \sim 10$ & -1.01 & 0.08 & 49.1 & 1.3 & 0.48 & 0.03 & 69.8 & 10.1 & 0.69 & 0.02 & 88.1 & 7.9 & 206.9 & 12.9 & 0.21 & 0.001 \\
\hline $13 \sim 14$ & -0.99 & 0.06 & 47.2 & 1.1 & 0.43 & 0.01 & 66.6 & 1.5 & 0.67 & 0.02 & 92.7 & 1.2 & 206.5 & 2.2 & 0.21 & 0.000 \\
\hline $17 \sim 18$ & -1.17 & 0.08 & 51.7 & 3.9 & 0.55 & 0.03 & 61.1 & 1.3 & 0.70 & 0.02 & 78.5 & 3.0 & 191.4 & 5.1 & 0.14 & 0.001 \\
\hline $20 \sim 21$ & -1.21 & 0.01 & 48.3 & 1.8 & 0.48 & 0.02 & 64.7 & 1.3 & 0.67 & 0.02 & 74.1 & 12.2 & 187.2 & 12.4 & 0.12 & 0.001 \\
\hline 24 25 & -0.89 & 0.05 & 47.4 & 2.7 & 0.23 & 0.02 & 69.2 & 3.9 & 0.65 & 0.02 & 87.1 & 1.1 & 203.8 & 4.8 & 0.15 & 0.000 \\
\hline 26 27 & -0.97 & 0.08 & 56.7 & 2.8 & 0.43 & 0.02 & 62.0 & 3.3 & 0.72 & 0.02 & 80.5 & 5.5 & 199.2 & 7.0 & 0.15 & 0.001 \\
\hline 29 30 & -1.18 & 0.03 & 60.0 & 3.8 & 0.38 & 0.01 & 76.0 & 6.9 & 0.75 & 0.02 & 94.7 & 7.0 & 230.7 & 10.6 & 0.13 & 0.001 \\
\hline
\end{tabular}


Table A. 10. Summary of iron isotope measurements and mass balance calculation for Basin B, Tantaré.

\begin{tabular}{|c|c|c|c|c|c|c|c|c|c|c|c|c|c|c|c|c|}
\hline \multirow[b]{2}{*}{$\begin{array}{l}\text { Depth } \\
\text { (cm) }\end{array}$} & \multicolumn{4}{|c|}{ Extract 1} & \multicolumn{4}{|c|}{ Extract 2} & \multicolumn{4}{|c|}{ Extract 3} & \multirow[b]{2}{*}{$\mathrm{Fe}(\mathrm{tot})_{\text {sum }}$} & \multirow[b]{2}{*}{$1 S D$} & \multirow[b]{2}{*}{$\delta^{56} \mathrm{Fe}_{\text {balance }}$} & \multirow[b]{2}{*}{$1 S D$} \\
\hline & $\begin{array}{c}\delta^{56} \mathrm{Fe} \\
\% 0\end{array}$ & 1SD & $\begin{array}{c}\text { Fetot } \\
(\mu \mathrm{mol} / \mathrm{g})\end{array}$ & $1 S D$ & $\begin{array}{c}\delta^{56} \mathrm{Fe} \\
\% 0\end{array}$ & $1 S D$ & $\begin{array}{c}\text { Fetot } \\
(\mu \mathrm{mol} / \mathrm{g})\end{array}$ & $1 \mathrm{SD}$ & $\begin{array}{c}\delta^{56} \mathrm{Fe} \\
\%\end{array}$ & $1 \mathrm{SD}$ & $\begin{array}{c}\text { Fetot } \\
(\mu \mathrm{mol} / \mathrm{g})\end{array}$ & $1 \mathrm{SD}$ & & & & \\
\hline $0 \sim 0.5$ & $\begin{array}{c}-0.28 \\
\end{array}$ & 0.08 & 219.3 & 5.3 & 0.37 & 0.06 & 242.8 & 4.7 & 0.89 & 0.02 & 123.7 & 12.6 & 585.8 & 14.5 & 0.24 & 0.001 \\
\hline $0.5 \sim 1$ & -0.23 & 0.04 & 252.2 & 3.0 & 0.42 & 0.02 & 254.0 & 3.7 & 0.85 & 0.02 & 112.6 & 10.7 & 618.7 & 11.7 & 0.23 & 0.000 \\
\hline $1 \sim 1.5$ & -0.53 & 0.06 & 194.7 & 10.9 & 0.46 & 0.03 & 284.2 & 7.4 & 0.81 & 0.02 & 107.9 & 0.3 & 586.8 & 13.2 & 0.20 & 0.000 \\
\hline $1.5 \sim 2$ & -0.55 & 0.03 & 195.2 & 1.5 & 0.44 & 0.06 & 276.7 & 16.0 & 0.77 & 0.02 & 115.7 & 5.9 & 587.6 & 17.1 & 0.18 & 0.001 \\
\hline 3.5 4 & -0.57 & 0.08 & 186.7 & 1.9 & 0.45 & 0.10 & 249.5 & 8.5 & 0.73 & 0.02 & 129.8 & 1.8 & 565.9 & 8.9 & 0.18 & 0.001 \\
\hline $4.5 \sim 5$ & -0.19 & 0.01 & 231.6 & 6.2 & 0.59 & 0.07 & 131.6 & 0.1 & 0.69 & 0.02 & 120.0 & 6.1 & 483.3 & 8.7 & 0.24 & 0.000 \\
\hline $6.5 \sim 7$ & -0.20 & 0.03 & 211.5 & 6.4 & 0.37 & 0.12 & 119.7 & 8.0 & 0.65 & 0.02 & 132.3 & 8.5 & 463.5 & 13.3 & 0.19 & 0.001 \\
\hline 9 9.5 & -0.57 & 0.02 & 179.4 & 0.2 & 0.51 & 0.05 & 163.8 & 6.6 & 0.62 & 0.01 & 168.7 & 5.0 & 511.8 & 8.3 & 0.17 & 0.000 \\
\hline $10 \sim 11$ & -0.25 & 0.01 & 193.8 & 0.4 & 0.68 & 0.11 & 134.8 & 0.8 & 0.70 & 0.02 & 146.5 & 6.8 & 475.2 & 6.9 & 0.31 & 0.001 \\
\hline $15 \sim 16$ & -0.24 & 0.08 & 178.8 & 0.3 & 0.40 & 0.00 & 111.6 & 2.3 & 0.78 & 0.02 & 131.5 & 3.7 & 421.9 & 4.4 & 0.24 & 0.001 \\
\hline 22 23 & -0.22 & 0.08 & 183.8 & 4.6 & 0.23 & 0.00 & 104.5 & 1.4 & 0.86 & 0.02 & 129.4 & 12.5 & 417.7 & 13.4 & 0.23 & 0.001 \\
\hline 28 29 & -0.24 & 0.01 & 200.2 & 4.8 & 0.28 & 0.00 & 111.8 & 2.1 & 0.94 & 0.02 & 139.3 & 7.0 & 451.4 & 8.7 & 0.25 & 0.000 \\
\hline
\end{tabular}


Table A. 11. Comparison of $\mathrm{Fe}$ isotope compositions in different aquatic systems.

\begin{tabular}{|c|c|c|c|c|c|c|c|}
\hline $\begin{array}{l}\text { Aquatic } \\
\text { systems }\end{array}$ & $\begin{array}{l}\mathrm{O}_{2} \text { in water } \\
\text { column }\end{array}$ & $\begin{array}{l}\text { Fe minerals in } \\
\text { sediments }\end{array}$ & $\begin{array}{l}\delta^{56} \mathrm{Fe}^{\mathrm{a}}(\%) \text { of } \mathrm{Fe} \\
\text { in water column }\end{array}$ & $\begin{array}{l}\delta^{56} \mathrm{Fe}^{\mathrm{a}}(\%) \text { of } \\
\text { pore water }\end{array}$ & $\bar{c}^{56} \mathrm{Fe}^{\mathrm{a}}(\%)$ of sediments & $\begin{array}{l}\text { Origin of } \\
\text { isotopically } \\
\text { light Fe }\end{array}$ & Reference \\
\hline $\begin{array}{l}\text { Lakes } \\
\text { Tantaré, } \\
\text { basin A }\end{array}$ & $\begin{array}{l}\text { Permanently oxic } \\
\left(\mathrm{O}_{2} \text { depleted }\right. \\
\text { within } 5 \mathrm{~mm} \text { of } \\
\text { sediment })\end{array}$ & $\begin{array}{l}\text { Fe oxyhydroxides, } \\
\text { mainly ferrihydrite, } \\
\text { lepidocrocite and } \\
\text { goethite }\end{array}$ & $N D^{b}$ & $\begin{array}{l}-2.1 \text { to }-0.9(- \\
1.3 \pm 0.4^{c} \\
n=12)\end{array}$ & $\begin{array}{l}-0.9 \pm 0.2\left(e^{2 x t 1^{d}}, n=20\right) \\
0.4 \pm 0.1\left(e^{d} 2^{d}, n=18\right) \\
0.6 \pm 0.2\left(e^{d} 3^{d}, n=19\right)\end{array}$ & $\operatorname{DIR}^{\mathrm{e}}$ & This study \\
\hline $\begin{array}{l}\text { Tantaré, } \\
\text { basin B }\end{array}$ & $\begin{array}{l}\text { Seasonally } \\
\text { anoxic bottom } \\
\text { water }\end{array}$ & $\mathrm{N} / \mathrm{A}^{\mathrm{b}}$ & ND & ND & $\begin{array}{l}-0.6 \pm 0.2(\operatorname{ext} 1, n=12) \\
0.4 \pm 0.1(\operatorname{ext} 2, n=12) \\
0.8 \pm 0.2(\operatorname{ext} 3, n=3)\end{array}$ & DIR & This study \\
\hline Pavin & $\begin{array}{l}\text { Anoxic below } \sim 60 \\
\mathrm{~m}\end{array}$ & $\begin{array}{l}\text { Siderite, vivianite, } \\
\text { and iron sulfide }\end{array}$ & $\begin{array}{l}-2.2 \text { to } 0.2 \\
\text { (water, } n=18 \text { ) }\end{array}$ & $\begin{array}{l}-0.5 \text { to } 0.5 \\
(-0.05 \pm 0.04 \\
n=36)\end{array}$ & $\begin{array}{l}0.0 \pm 0.1(\text { bulk, } n=38) \\
-0.04 \pm 0.02(\mathrm{HCl} \text { leach, } \\
n=26)\end{array}$ & $\begin{array}{l}\text { Partial } \\
\text { oxidation of } \\
\mathrm{Fe}(\mathrm{II})\end{array}$ & $\begin{array}{l}\text { Busigny et } \\
\text { al., } 2014\end{array}$ \\
\hline Geneva & Oxic & $\begin{array}{l}\text { Magnetite, } \\
\text { maghemite, } \\
\text { hematite, and Fe } \\
\text { silicates }\end{array}$ & ND & $\begin{array}{l}-1.8 \text { to }-0.6(- \\
1.1 \pm 0.5, n=4)\end{array}$ & $\begin{array}{l}0.1 \pm 0.05(\text { bulk, } n=7) \\
0.1 \pm 0.2(\mathrm{HCl} \text { leach, } n=8) \\
0.1 \pm 0.05(\text { Fe silicates, } n=4)\end{array}$ & DIR & $\begin{array}{l}\text { Percak- } \\
\text { Dennett et } \\
\text { al., } 2013\end{array}$ \\
\hline Vettasjarvi & $\begin{array}{l}\text { Anoxic below } \sim 16 \\
\mathrm{~m}\end{array}$ & $\mathrm{~N} / \mathrm{A}$ & $\begin{array}{l}-1.1 \text { (water, } \mathrm{n}=1) \\
-0.9 \text { to }-0.1 \\
\left(\mathrm{SM}^{\mathrm{d}}, \mathrm{n}=6\right)\end{array}$ & ND & ND & $\begin{array}{l}\text { Partial } \\
\text { oxidation of } \\
\mathrm{Fe}(\mathrm{II})\end{array}$ & $\begin{array}{l}\text { Malinovsky } \\
\text { et al., } 2005\end{array}$ \\
\hline Kutsasjarvi & $\begin{array}{l}\text { Oxic (anoxic } \\
\text { below } 11 \mathrm{~cm} \text { in } \\
\text { sediments) }\end{array}$ & $\mathrm{N} / \mathrm{A}$ & $\begin{array}{l}-0.5 \text { to }-0.3 \\
\left(\mathrm{SM}^{\mathrm{d}}, \mathrm{n}=2\right)\end{array}$ & ND & -0.2 to -0.03 (bulk, $n=3$ ) & $\begin{array}{l}\text { Partial } \\
\text { oxidation of } \\
\mathrm{Fe}(\mathrm{II})\end{array}$ & $\begin{array}{l}\text { Malinovsky } \\
\text { et al., } 2005\end{array}$ \\
\hline \multicolumn{8}{|l|}{ Aquifers } \\
\hline Mine tailings & $\mathrm{N} / \mathrm{A}$ & $\begin{array}{l}\text { Pyrite, Fe sulfide } \\
\text { minerals, iron- } \\
\text { bearing silicates }\end{array}$ & ND & $\begin{array}{l}-2.4 \text { to }-1.2 \\
\text { (oxidized } \\
\text { tailings, } n=2 \text { ) } \\
-1.3 \text { to }-0.3 \\
\text { (unoxidized } \\
\text { tailings, } n=6 \text { ) }\end{array}$ & $\begin{array}{l}-1.0 \text { to }-0.7 \text { (oxidized bulk, } \\
n=5) \\
-0.4 \text { to }-0.03 \text { (unoxidized } \\
\text { bulk, } n=3 \text { ) }\end{array}$ & $\begin{array}{l}\text { Microbial } \\
\text { Fe(II) } \\
\text { oxidation }\end{array}$ & $\begin{array}{l}\text { Herbert and } \\
\text { Schippers, } \\
2008\end{array}$ \\
\hline $\begin{array}{l}\text { Mine } \\
\text { drainage }\end{array}$ & $\mathrm{N} / \mathrm{A}$ & Fe oxyhydroxides & ND & $\begin{array}{l}-1.5 \text { to }-0.2 \\
(n=11)\end{array}$ & $\begin{array}{l}-0.3 \text { to } 0.2(\text { bulk, } n=11) \\
-0.5 \text { to } 0.0(\text { ext1, n=6) } \\
0.1 \text { to } 0.6(\text { ext2, } n=11)\end{array}$ & DIR & $\begin{array}{l}\text { Tangalos et } \\
\text { al., } 2010\end{array}$ \\
\hline
\end{tabular}




\begin{tabular}{|c|c|c|c|c|c|c|c|}
\hline & & & & & -0.3 to $0.3(e x t 3, n=11)$ & & \\
\hline Groundwater & $\mathrm{N} / \mathrm{A}$ & $\mathrm{N} / \mathrm{A}$ & $\begin{array}{l}-3.5 \text { to } 0.6 \\
(n=65)\end{array}$ & $\begin{array}{l}-2.2 \text { to }-0.8 \\
(n=3)\end{array}$ & $\begin{array}{l}-1.2 \text { to } 0.7 \text { (bulk, } n=55) \\
-0.5 \text { to } 0.3 \text { (Fe oxides, } \\
n=54)\end{array}$ & $\begin{array}{l}\text { DIR, } \\
\text { sorption, and } \\
\text { partial Fe(II) } \\
\text { oxidation }\end{array}$ & $\begin{array}{l}\text { Teutsch et } \\
\text { al., 2005; } \\
\text { Guo et al., } \\
\text { 2013; Xie et } \\
\text { al., 2013; } \\
2014\end{array}$ \\
\hline $\begin{array}{l}\text { Marine } \\
\text { sediments }\end{array}$ & $N / A$ & $\mathrm{~N} / \mathrm{A}$ & $\begin{array}{l}-3.5 \text { to }-0.1 \\
\text { (seawater, } n=41)\end{array}$ & $\begin{array}{l}-3.5 \text { to } 1.1 \\
(n=150)\end{array}$ & $\begin{array}{l}-0.7 \text { to } 0.4 \text { (bulk, } n=206) \\
-0.9 \text { to } 1.0 \text { ( } \mathrm{HCl} \text { leach, } \\
\mathrm{n}=81) \\
-1.7 \text { to } 0.2 \text { (pyrite, } \mathrm{n}=73 \text { ) }\end{array}$ & $\begin{array}{l}\text { benthic Fe } \\
\text { shuttle from } \\
\text { DIR }\end{array}$ & $\begin{array}{l}\text { Fehr et al., } \\
\text { 2008;2010; } \\
\text { Severmann } \\
\text { et al., 2006; } \\
\text { 2008;2010;St } \\
\text { aubwasser et } \\
\text { al., 2006 } \\
\text { Homoky et } \\
\text { al., 2009; } \\
2013 ; \text { Scholz } \\
\text { et al., } \\
2014 \text { a,b }\end{array}$ \\
\hline $\begin{array}{l}\text { Estuarine } \\
\text { sediments }\end{array}$ & $\mathrm{N} / \mathrm{A}$ & $\mathrm{N} / \mathrm{A}$ & $\begin{array}{l}-0.9 \text { to } 0.4 \\
\text { (groundwater, } \\
n=6 \text { ) }\end{array}$ & $\begin{array}{l}-1.4 \text { to } 0.3 \\
\text { (fresh, } n=14 \text { ) } \\
-5.0 \text { to } 0.7 \\
\text { (brackish, } \\
n=48 \text { ) }\end{array}$ & -1.9 to 1.5 (bulk, $n=55)$ & $\begin{array}{l}\text { Partial Fe(II) } \\
\text { oxidation, } \\
\text { DIR, sorption }\end{array}$ & $\begin{array}{l}\text { Rouxel et al., } \\
\text { 2008; Roy et } \\
\text { al., } 2012\end{array}$ \\
\hline
\end{tabular}

${ }^{a} \mathrm{All} \delta^{56} \mathrm{Fe}$ values in cited references were converted to igneous rock standard according to $\delta^{56} \mathrm{Fe}$ of IRMM-014 $\mathrm{Fe}=-0.09 \%$.

${ }^{\mathrm{b}} \mathrm{ND}$ denotes not determined, N/A denotes not available.

${ }^{c}$ Number denotes average \pm 1 standard deviation, $\mathrm{n}$ is sample number excluding duplicates.

d ext1 is $0.1 \mathrm{M} \mathrm{HCl}$ extract, ext2 is $0.5 \mathrm{M} \mathrm{HCl}$ extract, ext3 is $7 \mathrm{M} \mathrm{HCl}$ extract, $\mathrm{SM}$ denotes suspended matter.

${ }^{\mathrm{e}} \mathrm{DIR}$ denotes dissimilatory iron reduction. 


\section{a) Mass balance calculations for different iron phases}

1) Isotope composition for pore water $\mathrm{Fe}(\mathrm{II})\left(\delta^{56} \mathrm{Fe} \mathrm{pw}_{\mathrm{Fe}(\mathrm{II})}\right)$ is calculated based on the following equation: $\delta^{56} \mathrm{Fe}_{\mathrm{pw}} \cdot\left[\mathrm{Fe}_{\mathrm{tot}}\right]_{\mathrm{pw}}=\delta^{56} \mathrm{Fe}_{\mathrm{pw} \mathrm{Fe}(\mathrm{II})} \cdot[\mathrm{Fe}(\mathrm{II})]_{\mathrm{pw}}+\delta^{56} \mathrm{Fe}_{\mathrm{pw} \mathrm{Fe}(I I I)} \cdot[\mathrm{Fe}(\mathrm{III})]_{\mathrm{pw}}$ Eq.1 Where $\delta^{56} \mathrm{Fe}_{\mathrm{pw}}$ is measured isotope composition for pore water, $\delta^{56} \mathrm{Fe} \mathrm{pw}_{\mathrm{Fe}(I I I)}$ is the isotope composition for pore water $\mathrm{Fe}(\mathrm{III})$, which is assumed to be equal to that of solid-phase $\mathrm{Fe}(\mathrm{III})$ oxyhydroxides $\left(\delta^{56} \mathrm{Fe}\right.$ value of extract 3$)$, $\left[\mathrm{Fe} \mathrm{tot}_{\mathrm{pw}}\right.$ is the total Fe concentration in pore water, determined by ferrozine method after adding hydroxylamine hydrochloride, $[\mathrm{Fe}(\mathrm{II})]_{\mathrm{pw}}$ is the pore water $\mathrm{Fe}(\mathrm{II})$ concentration determined directly by ferrozine method, $[\mathrm{Fe}(\mathrm{III})]_{\mathrm{pw}}$ is the pore water $\mathrm{Fe}(\mathrm{III})$ concentration calculated by the difference between $\left[\mathrm{Fe}_{\text {tot }}\right]$ and $[\mathrm{Fe}(\mathrm{II})]$.

2) Isotope composition for sorbed $\mathrm{Fe}(\mathrm{II})\left(\delta^{56} \mathrm{Fe}\right.$ sorbed $\left.\mathrm{Fe}(\mathrm{II})\right)$ is calculated based on the following equation:

$\delta^{56} \mathrm{Fe}_{\text {ext1 }} \cdot\left[\mathrm{Fe}_{\text {tot }}\right]_{\text {ext1 }}=\delta^{56} \mathrm{Fe}_{\text {sorbed } \mathrm{Fe}(\mathrm{II})} \cdot[\mathrm{Fe}(\mathrm{II})]_{\mathrm{ext} 1}+\delta^{56} \mathrm{Fe} \mathrm{Fe}(\mathrm{III}) \cdot[\mathrm{Fe}(\mathrm{III})]_{\mathrm{ext} 1}$

Where $\delta^{56} \mathrm{Fe}_{\text {ext } 1}$ is measured isotope composition for extract $1(0.1 \mathrm{M} \mathrm{HCl}), \delta^{56} \mathrm{Fe} F($ (III) is the isotope composition for $\mathrm{Fe}(\mathrm{III})$ in extract 1 , which is assumed to be equal to that of solid-phase $\mathrm{Fe}(\mathrm{III})$ oxyhydroxides $\left(\delta^{56} \mathrm{Fe}\right.$ value of extract 3$)$, [Fe $\mathrm{tot}_{\mathrm{ext} 1}$ is the total Fe concentration in extract 1, $[\mathrm{Fe}(\mathrm{II})]_{\text {ext } 1}$ is the $\mathrm{Fe}(\mathrm{II})$ concentration in extract 1, $[\mathrm{Fe}(\mathrm{III})]_{\text {ext } 1}$ is the $\mathrm{Fe}(\mathrm{III})$ concentration in extract 1 .

3) Isotope composition for tightly-bound $\mathrm{Fe}(\mathrm{II})\left(\delta^{56} \mathrm{Fe}\right.$ tightly-bound $\left.\mathrm{Fe}(\mathrm{II})\right)$ is calculated based on the following equation: $\delta^{56} \mathrm{Fe}_{\text {ext2 }} \cdot\left[\mathrm{Fe}_{\text {tot }}\right]_{\text {ext2 }}=\delta^{56} \mathrm{Fe}_{\text {tightly-bound } \mathrm{Fe}(\mathrm{II})} \cdot[\mathrm{Fe}(\mathrm{II})]_{\mathrm{ext2}}+\delta^{56} \mathrm{Fe} \mathrm{Fe}(\mathrm{III}) \cdot[\mathrm{Fe}(\mathrm{III})]_{\text {ext2 }}$ 
Where $\delta^{56} \mathrm{Fe}_{\text {ext2 }}$ is measured isotope composition for extract $2(0.5 \mathrm{M} \mathrm{HCl}), \delta^{56} \mathrm{Fe}$ Fe(III) is the isotope composition for $\mathrm{Fe}(\mathrm{III})$ in extract 2, which is assumed to be equal to that of solid-phase $\mathrm{Fe}(\mathrm{III})$ oxyhydroxides $\left(\delta^{56} \mathrm{Fe}\right.$ value of extract 3$)$, [Fe $\mathrm{Ftot}_{\mathrm{ext} 2}$ is the total Fe concentration in extract 2, $[\mathrm{Fe}(\mathrm{II})]_{\text {ext2 }}$ is the $\mathrm{Fe}(\mathrm{II})$ concentration in extract 2, $[\mathrm{Fe}(\mathrm{III})]_{\text {ext2 }}$ is the $\mathrm{Fe}(\mathrm{III})$ concentration in extract 2.

4) Isotope composition for $\mathrm{Fe}(\mathrm{III})$ oxyhydroxides $\left(\delta^{56} \mathrm{Fe} \mathrm{Fe}_{(I I I)}\right)$ is assumed to be the same as that of extract 3 .

b) Calculation of Fe isotope composition for original pore water $\mathrm{Fe}$ (II) if pore water $\mathrm{Fe}$ (III) was due to oxidation of Fe(II) during sampling and storage

Consider that the original pore water was all $\mathrm{Fe}(\mathrm{II})$ with an isotope composition of $\delta^{56} \mathrm{Fe} \mathrm{Fe}_{(I) 0}$ and a concentration of [Fe(II) $]_{0}$, if partial oxidation occurs, according to mass balance, we can get

$$
\delta^{56} \mathrm{Fe}_{\mathrm{Fe}(\mathrm{II}) 0} \cdot[\mathrm{Fe}(\mathrm{II})]_{0}=\delta^{56} \mathrm{Fe}_{\mathrm{pw} \mathrm{Fe}(\mathrm{II})} \cdot[\mathrm{Fe}(\mathrm{II})]_{\mathrm{pw}}+\delta^{56} \mathrm{Fe}_{\mathrm{pw} \mathrm{Fe}(I I I)} \cdot[\mathrm{Fe}(\mathrm{III})]_{\mathrm{pw}} \quad \text { Eq.4 }
$$

Comparing Eq.4 with Eq.1 and considering $[\mathrm{Fe}(\mathrm{II})]_{0}=\left[\mathrm{Fe}_{\mathrm{tot}}\right]_{\mathrm{pw}}$ because we assume $\mathrm{Fe}(\mathrm{III})$ in pore water was due to partial oxidation of $\mathrm{Fe}(\mathrm{II})$, we can get that $\delta^{56} \mathrm{Fe} \mathrm{Fe}_{\mathrm{II}) 0}=\delta^{56} \mathrm{Fe}_{\mathrm{pw}}$, which means that the original $\mathrm{Fe}(\mathrm{II})$ has the same isotope composition as that of measured pore water. 

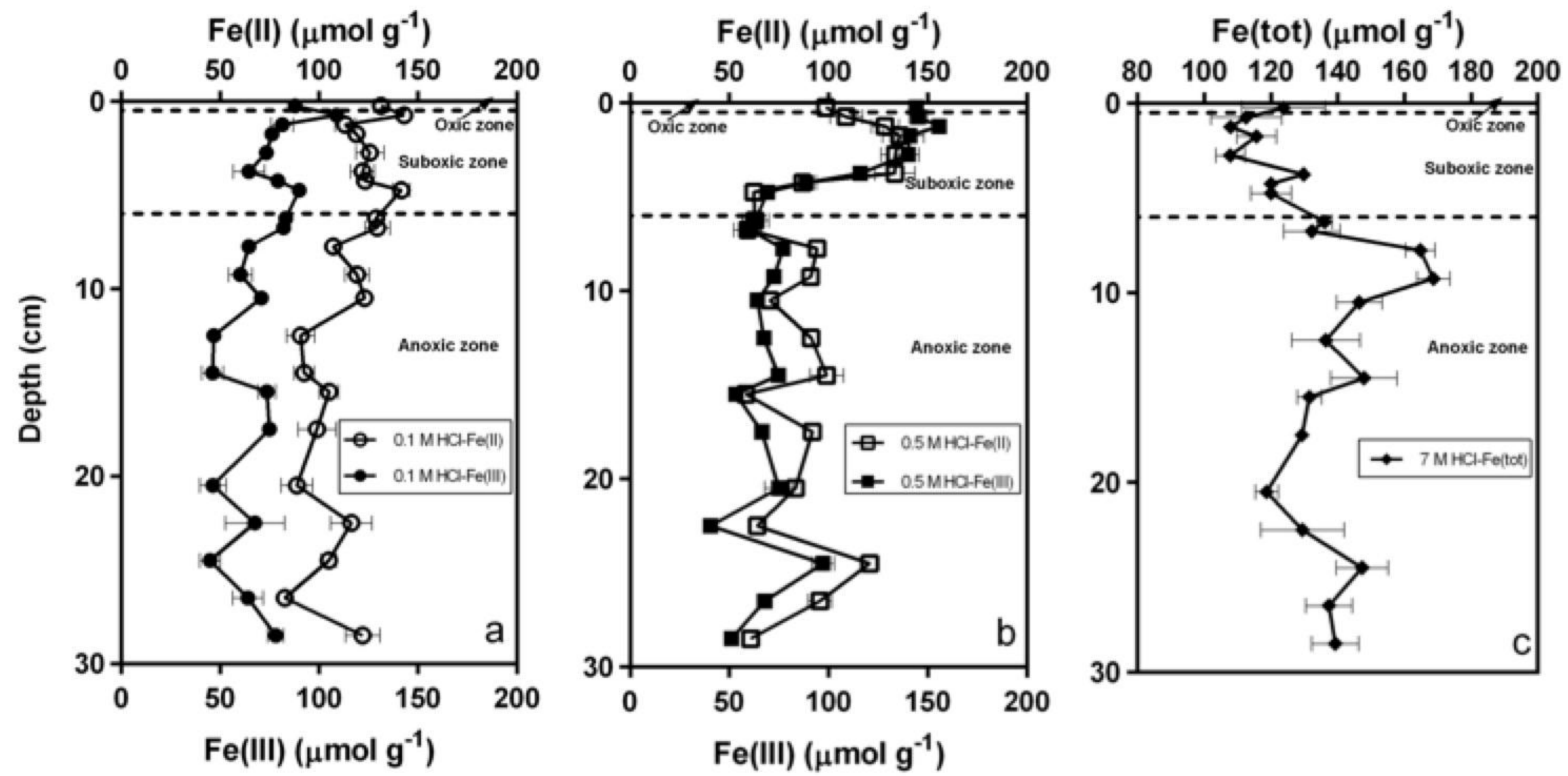

Fig. A. 1. Depth profiles of the concentrations of $\mathrm{Fe}(\mathrm{II})$ and $\mathrm{Fe}(\mathrm{III})$ for sediment extractions in Basin B. The horizontal dashed lines represents the sedimentwater interface (SWI). Error bars indicate errors (1SD) for two duplicate sediment samples. Panels a-c represent iron concentrations for Basin B: (a) Extract $(0.1 \mathrm{M} \mathrm{HCl})$; (b) Extract $2(0.5 \mathrm{M} \mathrm{HCl}) ;$ (c) Extract $3(7 \mathrm{M} \mathrm{HCl})$. 


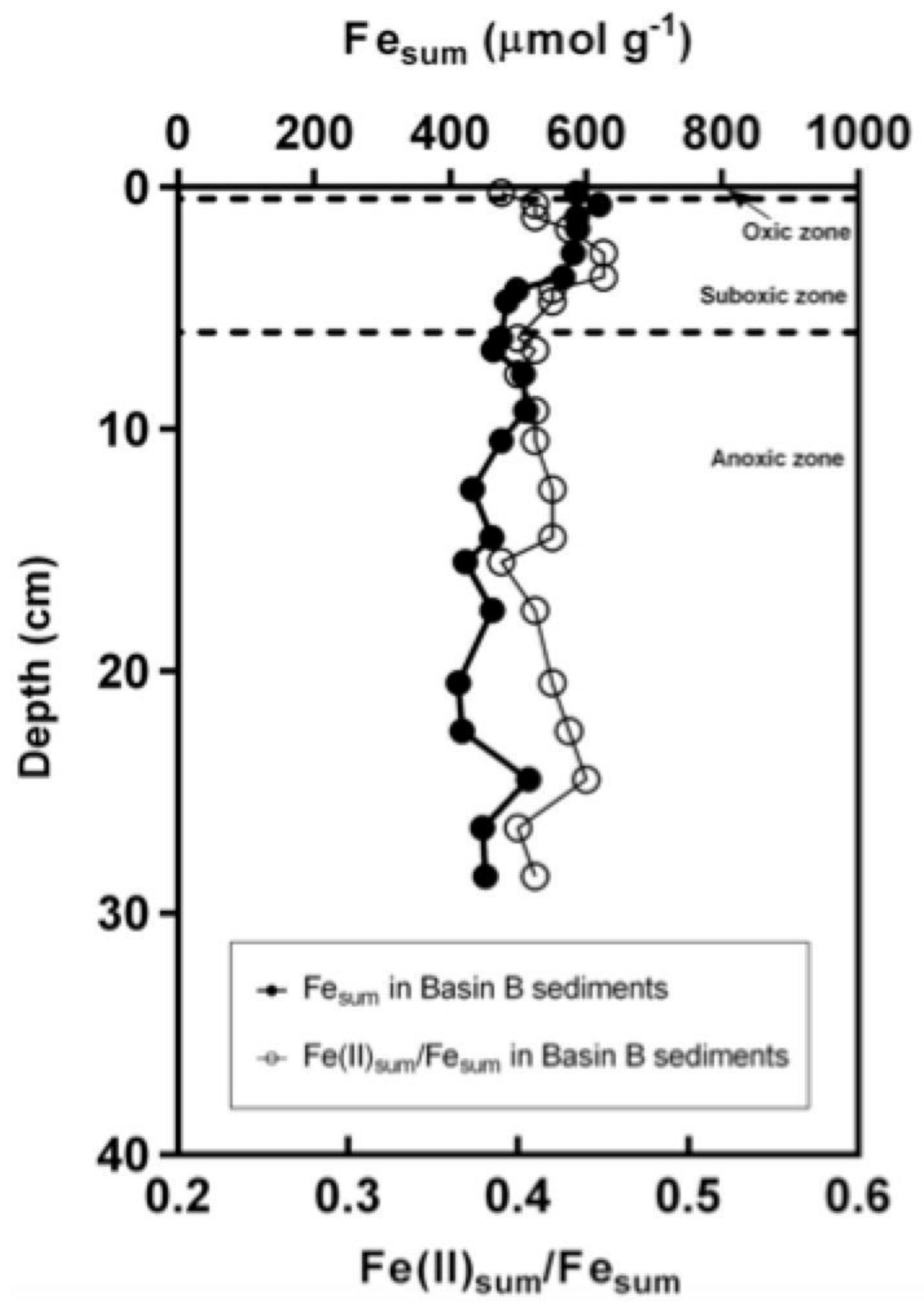

Fig. A. 2. Depth profiles of the concentration of total $\mathrm{Fe}\left(\mathrm{Fe}_{\text {sum }}\right)$ and $\mathrm{Fe}(\mathrm{II}) /$ total Fe ratio ( $\left.\mathrm{Fe}(\mathrm{II})_{\text {sum }} / \mathrm{Fe}_{\text {sum }}\right)$ for bulk sediments in Basin B. Error bars indicate errors for two duplicate sediment samples. 

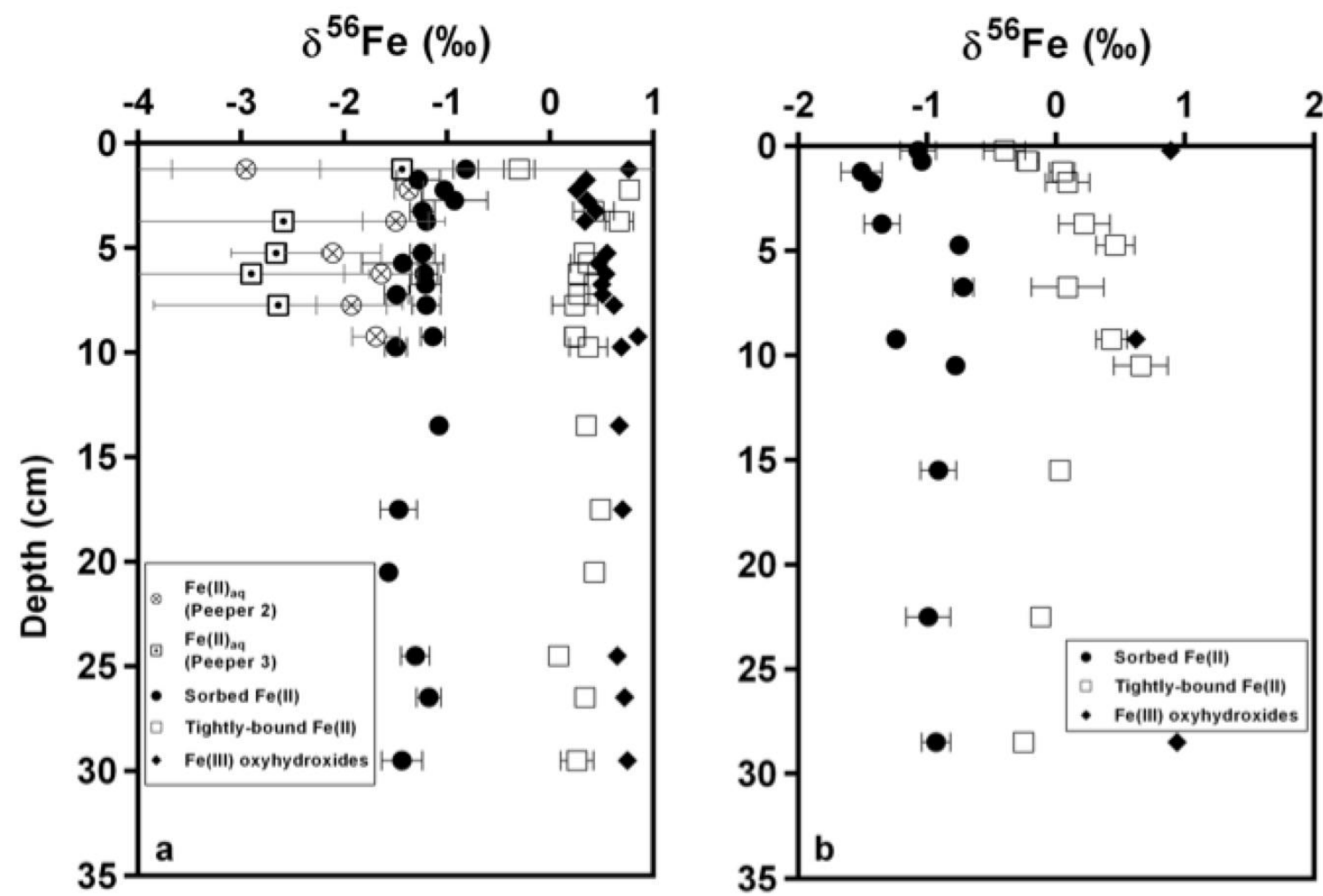

Fig. A. 3. Calculated iron isotope compositions for different Fe phase(pore water $\mathrm{Fe}(\mathrm{II})$, sorbed $\mathrm{Fe}(\mathrm{II})$,tightly-bound $\mathrm{Fe}(\mathrm{II})$ and $\mathrm{Fe}(\mathrm{III})$ oxyhydroxides) in Basin A ( panel a) and Basin B (panel b). $\delta^{56} \mathrm{Fe}$ is calculated based on measured iron isotope compositions for pore water and acid extractions and the percentage of $\mathrm{Fe}(\mathrm{II})$ and $\mathrm{Fe}(\mathrm{III})$ concentrations in the pore water and Extract 1 and 2. See text for details. The large propagated error for aqueous $\mathrm{Fe}(\mathrm{II})$ in panel a was associated with extremely low concentration of $\mathrm{Fe}(\mathrm{II})$. 